\title{
Genetics and Epigenetics of Parathyroid Carcinoma
}

\author{
Francesca Marini ${ }^{1,2}$, Francesca Giusti ${ }^{1}$, Gaia Palmini ${ }^{1}$, Giuliano Perigli ${ }^{3}$, Roberto Santoro ${ }^{3}$ \\ and Maria Luisa Brandi ${ }^{2 *}$ \\ ${ }^{1}$ Department of Experimental and Clinical Biomedical Sciences, University of Florence, Florence, Italy, ${ }^{2}$ Fondazione Italiana \\ per la Ricerca sulle Malattie dell'Osso (F.I.R.M.O.) Italian Foundation for the Research on Bone Diseases, Florence, Italy, \\ ${ }^{3}$ Department of Experimental and Clinical Medicine, University of Florence, Azienda Ospedaliero-Universitaria (AOU)-Careggi, \\ Florence, Italy
}

Parathyroid carcinoma $(\mathrm{PC})$ is an extremely rare malignancy, accounting less than $1 \%$ of all parathyroid neoplasms, and an uncommon cause of primary hyperparathyroidism (PHPT), characterized by an excessive secretion of parathyroid hormone (PTH) and severe hypercalcemia. As opposed to parathyroid hyperplasia and adenomas, PC is associated with a poor prognosis, due to a commonly unmanageable hypercalcemia, which accounts for death in the majority of cases, and an overall survival rate of $78-85 \%$ and $49-70 \%$ at 5 and 10 years after diagnosis, respectively. No definitively effective therapies for PC are currently available. The mainly employed treatment for PC is the surgical removal of tumoral gland(s). Post-surgical persistent or recurrent disease manifest in about 50\% of patients. The comprehension of genetic and epigenetic bases and molecular pathways that characterize parathyroid carcinogenesis is important to distinguish malignant PCs from benign adenomas, and to identify specific targets for novel therapies. Germline heterozygote inactivating mutations of the CDC73 tumor suppressor gene, with somatic loss of heterozygosity at 1 q31.2 locus, account for about 50-75\% of familial cases; over $75 \%$ of sporadic PCs harbor biallelic somatic inactivation/loss of CDC73. Recurrent mutations of the PRUNE2 gene, a recurrent mutation in the ADCK1 gene, genetic amplification of the CCND1 gene, alterations of the PI3K/AKT/mTOR signaling pathway, and modifications of microRNA expression profile and gene promoter methylation pattern have all been detected in PC. Here, we review the current knowledge on gene mutations and epigenetic changes that have been associated with the development of PC, in both familial and sporadic forms of this malignancy.

Keywords: parathyroid carcinoma, gene mutation, tumor suppressor genes, molecular signatures, epigenetic changes, DNA methylation, microRNAs, long non-coding RNAs

\section{PARATHYROID CARCINOMA}

Parathyroid tumors are rare endocrine neoplasms affecting $0.1-0.3 \%$ of the general population (1); less than $1 \%$ of are malignant parathyroid carcinomas (PCs). Age at diagnosis of PCs is commonly in the mid fifth decade of life, usually 10 years earlier than benign parathyroid adenomas (PAs), with no gender prevalence. PC most commonly occurs as a sporadic single-gland disease, without a familial 
history, with only a minority of cases manifesting as isolated inherited cancer or as part of a complex hereditary syndrome.

The great majority of PCs are functioning tumors oversecreting parathyroid hormone $(\mathrm{PTH})$, responsible for primary hyperparathyroidism (PHPT) and elevated serum levels of calcium; only $2 \%$ of PCs are non-functioning variants characterized by normal serum calcium and PTH values, manifesting through compressive signs and symptoms of local invasion (1). Contrary to parathyroid hyperplasia and adenomas, PCs are associated with poor prognosis due to more severely elevated PTH, and higher, commonly unmanageable, hypercalcemia, which accounts for death in a majority of cases, with an overall survival rate of $78-85 \%$ and $49-70 \%$ at 5 and 10 years after diagnosis, respectively (2). Moreover, $10-30 \%$ patients with PC already have metastatic disease at diagnosis, most commonly in the lungs, bone, or liver (3).

The absence of distinctive growth and histological characteristics, as well as of idiosyncratic serum concentration values of calcium ion and intact $\mathrm{PTH}$, distinguishing malignant PCs from PAs, makes a clear pre-operative histopathological or biochemical diagnosis of PCs extremely difficult. A diagnosis of malignancy usually occurs during surgery, through an intraoperative assessment of a marked local invasion of adjacent structures and surrounding lymph nodes, and/or confirmed during a prolonged post-operative follow-up in presence of local relapses or distant metastases. Since PCs require a more radical surgical approach than benign PAs, with en bloc gland resection and tumor safety margins, often including the excision of the adjacent ipsilateral thyroid lobe and thymus, a misdiagnosis may lead to inadequate surgical resection and a high recurrence rate and risk of distant metastases. Currently, up to $50 \%$ of PC patients manifest metastases following an initial wrong diagnosis of benign disease, with a consequent severe impairment of the prognosis and reduction of overall survival (4).

In this light, the identification of distinctive genetic bases, epigenetic changes, and molecular signatures characterizing parathyroid malignancies is fundamental to identify potential diagnostic biomarkers able to clearly distinguish PCs from benign parathyroid tumors, as well to provide potential therapeutic targets for these malignant neoplasms.

\section{GENETICS OF PARATHYROID CARCINOMA}

PCs occur either as sporadic non-hereditary single-gland disease, or as isolated inherited malignancy in a percentage of patients with familial isolated primary hyperparathyroidism (FIPH), or in the context of hyperparathyroidism-jaw tumor (HPT-JT) syndrome, affecting about $15 \%$ of HPT-JT patients. Studies on hereditary and sporadic forms of PCs revealed specific germline and somatic genetic alterations underlying PC development (Table 1).

Extremely rare cases of malignant PCs have been reported in Multiple Endocrine Neoplasia type 1 (MEN1) syndrome (less than 15 cases) and in Multiple Endocrine Neoplasia type 2A (MEN2A) syndrome (only two cases), as a consequence of germline heterozygote inactivating mutations of the MEN1 tumor suppressor gene and germline heterozygote activating mutations of the RET proto-oncogene, respectively (5). No genotype-phenotype correlation has been found to explain why these few individuals develop PCs instead of PAs, which typically affect patients with MEN1 and MEN2A.

\section{CDC73 Gene}

Biallelic loss-of-function mutations/inactivation of the Cell Division Cycle 73 (CDC73) tumor suppressor gene are the major driver genetic defects in the etiology of PCs and, since they are found in less than $1 \%$ of benign PAs (12), they can be considered the main genetic hallmark of parathyroid malignancy risk.

In the hereditary forms (HPT-JT- and FIPH-related cancers), CDC73 mutations comprise one germline mutation and one somatic inactivation/loss of the gene, the first inherited from the affected parent, and the second occurring in the parathyroid cell, often as chromosomal loss at 1q31.2. Germline inactivating mutations of the CDC73 gene are detected in $50-75 \%$ of HPTJT families $(5,6)$, and in about $8 \%$ of FIPH pedigrees (13). Over $85 \%$ of germline CDC73 mutations in hereditary PCs are frameshift and nonsense variants that create a premature stop codon, predicting a truncated protein, while the second somatic hit involves loss of heterozygosity $(\mathrm{LOH})$ at the $1 \mathrm{q} 31.2$ locus in a great majority of cases.

In sporadic non-inherited PCs, both the CDC73 loss-offunction mutations occur at somatic level in the parathyroid cell. Somatic CDC73 mutations have been reported in $40-100 \%$ of sporadic PCs (5). Interestingly, germline CDC73 mutations are identified in $20-40 \%$ of patients with apparently sporadic PC (5), suggesting them as probable inherited diseases in those cases where the familial history is unknown, or cases of mosaicism with a germline mutation that originated de novo at the embryonic level (14). $\mathrm{LOH}$ at the CDC73 locus is reported in $50-55 \%$ of sporadic PCs (5). Hewitt et al. (14) showed hypermethylation of the CDC73 gene promoter in $18 \%(2 / 11)$ of sporadic PCs and 17\% (1/6) of PAs from HPT-JT patients, all without mutation of the CDC73 gene, but not in 37 sporadic PAs, suggesting this epigenetic gene-silencing tool as an additional mechanism by which loss of the CDC73 gene expression may give rise to PCs.

The CDC73 gene is located on chromosome 1q31.2 and consists of 17 exons encoding parafibromin, a ubiquitously expressed $60 \mathrm{KDa}$ protein that is an essential component of the Polymerase-Associated Factor 1 (PAF1) complex, whose main biological roles are resumed in Figure 1.

The PAF1 complex directly interacts with both the nonphosphorylated and the Ser2- and Ser5-phosphorylated forms of the RNA polymerase II large subunit, coordinating the correct recruitment of transcript elongation and RNA processing machineries (15). Moreover, the PAF1 complex is involved in coupling transcriptional and post-transcriptional events, in modulating the transition of gene transcripts from initiation to elongation steps, and in the mRNA 3'-end processing through modulation of the levels of Ser2 phosphorylation in the carboxyterminal domain (CTD) of the RNA polymerase II (15). The interaction between RNA polymerase II and PAF1 depends on 
TABLE 1 | Main genetic determinants in parathyroid carcinomas.

\begin{tabular}{|c|c|c|c|c|c|c|c|}
\hline Gene & $\begin{array}{l}\text { Gene type in } \\
\text { PC carcino- } \\
\text { genesis }\end{array}$ & $\begin{array}{l}\text { Chromosomal } \\
\text { location }\end{array}$ & $\begin{array}{l}\text { Type of } \\
\text { mutations }\end{array}$ & Encoded protein & $\begin{array}{l}\text { Frequency } \\
\text { in PCs }\end{array}$ & Encoded protein function(s) & $\begin{array}{c}\text { Molecular and cellular effects } \\
\text { of gene mutations }\end{array}$ \\
\hline $\begin{array}{l}\text { CDC73 } \\
(5,6)\end{array}$ & TSG & $1 \mathrm{q} 31.2$ & $\begin{array}{l}\text { Biallelic } \\
\text { inactivating } \\
\text { mutations/ } \\
\text { gene loss }\end{array}$ & Parafibromin & $\begin{array}{l}\text { Mutations in } \\
70-100 \% \\
\text { sporadic } \\
\text { PCs (5) } \\
\text { 1q31.2 LOH } \\
\text { in 50-55\% of } \\
\text { sporadic } \\
\text { PCs (5) } \\
\text { Mutations } \\
50-75 \% \text { of } \\
\text { HPT-JT } \\
\text { families }(5,6)\end{array}$ & $\begin{array}{l}\text { Regulation of transcript } \\
\text { elongation and stability via } \\
\text { interaction with the RNA } \\
\text { polymerase II. } \\
\text { Promotion of histone H3 } \\
\text { methylations leading to } \\
\text { transcriptionally active } \\
\text { chromatin structure. } \\
\text { Interaction with the SUV39H1 } \\
\text { histone methyltransferase } \\
\text { complex and promotion of } \\
\text { H3K9 methylation (H3K9me). } \\
\text { Interaction with the RNF20/ } \\
\text { RNF40 ubiquitin-ligase complex } \\
\text { and promotion of mono- } \\
\text { ubiquitination of the lysine 120 } \\
\text { on histone H2B (H2BK120ub1) }\end{array}$ & $\begin{array}{l}\text { Altered expression of genes } \\
\text { involved in cell cycle regulation. } \\
\text { Transcriptionally inactive } \\
\text { conformation of chromatin and } \\
\text { inhibition of gene expression. } \\
\text { Reduction of H3K9me and } \\
\text { subsequent increased } \\
\text { transcription of the CCND1 } \\
\text { gene. } \\
\text { Altered RNA elongation and } \\
\text { gene expression. }\end{array}$ \\
\hline $\begin{array}{l}\text { CCND1 } \\
(7,8)\end{array}$ & Proto-oncogene & $11 q 13.3$ & $\begin{array}{l}\text { Somatic gene } \\
\text { copy } \\
\text { amplifications }\end{array}$ & Cyclin D1 & $\begin{array}{l}\text { Gene } \\
\text { amplification } \\
\text { in about } \\
29 \% \text { of } \\
\text { cases (8) } \\
\text { Cyclin D1 } \\
\text { over- } \\
\text { expression } \\
\text { in about } \\
90 \% \text { of } \\
\text { cases (7) }\end{array}$ & $\begin{array}{l}\text { Positive regulator of cell cycle } \\
\text { progression by promoting the } \\
\text { G1 to S phase transition } \\
\text { through activation of CDK4 and } \\
\text { CDK6. }\end{array}$ & $\begin{array}{l}\text { Over-expression of cyclin D1 } \\
\text { protein. } \\
\text { Enhanced cell proliferation. } \\
\text { Enlarged hyperplastic } \\
\text { parathyroid glands. } \\
\text { Increased secretion of PTH. }\end{array}$ \\
\hline EZH2 (9) & Proto-oncogene & 7q36.1 & $\begin{array}{l}\text { Somatic gene } \\
\text { copy } \\
\text { amplifications }\end{array}$ & $\mathrm{EZH} 2$ & $\begin{array}{l}\text { About } 60 \% \\
\text { of sporadic } \\
\text { PCs (9) }\end{array}$ & $\begin{array}{l}\text { EZH } 2 \text { protein is a histone } 3 \\
\text { lysine } 27 \text { methyltransferase that } \\
\text { promotes the } \mathrm{H} 3 \mathrm{~K} 27 \mathrm{me} 3, \mathrm{a} \\
\text { histone modification that is } \\
\text { commonly associated with } \\
\text { transcriptional inhibition. }\end{array}$ & $\begin{array}{l}\text { Increased } \mathrm{H} 3 \mathrm{~K} 27 \mathrm{me} 3 \text { across } \\
\text { the genome and gene } \\
\text { expression repression. } \\
\text { Accumulation of the } \\
\text { transcriptionally active form of } \beta \text { - } \\
\text { catenin, and nuclear } \\
\text { transduction of the Wnt } \\
\text { signaling. }\end{array}$ \\
\hline $\begin{array}{l}\text { PRUNE2 } \\
(8,10)\end{array}$ & TSG & $9 q 21.2$ & $\begin{array}{l}\text { Germline } \\
\text { and/or } \\
\text { somatic } \\
\text { biallelic } \\
\text { inactivating } \\
\text { mutations/ } \\
\text { gene loss }\end{array}$ & $\begin{array}{l}\text { Prune Homolog } 2 \\
\text { with BCH Domain } \\
\text { (PRUNE2) }\end{array}$ & $\begin{array}{l}18 \% \text { of } \\
\text { sporadic } \\
\text { PCs }(10)\end{array}$ & $\begin{array}{l}\text { Suppression of Ras homolog } \\
\text { family member A activity, and } \\
\text { subsequent inhibition of } \\
\text { oncogenic cell transformation. }\end{array}$ & $\begin{array}{l}\text { Loss of control over cellular } \\
\text { transformation. }\end{array}$ \\
\hline $\begin{array}{l}\text { AKAP9 } \\
\text { (8) }\end{array}$ & TSG & $7 q 21.2$ & $\begin{array}{l}\text { Somatic } \\
\text { biallelic } \\
\text { inactivating } \\
\text { mutations }\end{array}$ & $\begin{array}{l}\text { A-Kinase Anchoring } \\
\text { Protein } 9 \text { (AKAP9) }\end{array}$ & $\begin{array}{l}17.6 \% \text { of } \\
\text { sporadic } \\
\text { PCs (8) }\end{array}$ & $\begin{array}{l}\text { Member of the A-kinase anchor } \\
\text { proteins that regulate cellular } \\
\text { localization and functions of the } \\
\text { protein kinase A. }\end{array}$ & $\begin{array}{l}\text { The biallelic inactivation } \\
\text { suggests the loss of a putative } \\
\text { tumor suppressor activity and } \\
\text { subsequent loss of the correct } \\
\text { cellular localization and function } \\
\text { of the protein kinase A. }\end{array}$ \\
\hline ZEB1 (8) & Proto-oncogene & $10 p 11.22$ & $\begin{array}{l}\text { Heterozygote } \\
\text { somatic } \\
\text { mutations }\end{array}$ & $\begin{array}{l}\text { Zinc Finger E-Box } \\
\text { Binding Homeobox } \\
1 \text { (ZEB1) }\end{array}$ & $\begin{array}{l}17.6 \% \text { of } \\
\text { sporadic } \\
\text { PCs (8) }\end{array}$ & $\begin{array}{l}\text { A zinc finger transcription factor } \\
\text { that acts as a transcriptional } \\
\text { repressor, represses E- } \\
\text { cadherin promoter, and } \\
\text { induces the epithelial- } \\
\text { mesenchymal transition (EMT) }\end{array}$ & $\begin{array}{l}\text { Activating mutations are } \\
\text { suspected to promote EMT and } \\
\text { tumor invasion and metastases. }\end{array}$ \\
\hline $\begin{array}{l}A D C K 1 \\
\text { (8) }\end{array}$ & $\begin{array}{l}\text { Proto- } \\
\text { oncogene? }\end{array}$ & $14 q 24$ & $\begin{array}{l}\text { A recurrent } \\
\text { heterozygote } \\
\text { somatic } \\
\text { missense } \\
\text { mutation }\end{array}$ & $\begin{array}{l}\text { AarF Domain } \\
\text { Containing Kinase } 1 \\
(\text { ADCK1) }\end{array}$ & $\begin{array}{l}11.8 \% \text { of } \\
\text { sporadic } \\
\text { PCs (8) }\end{array}$ & Still unknown. & Still unknown. \\
\hline
\end{tabular}


TABLE 1 | Continued

\begin{tabular}{|c|c|c|c|c|c|c|c|}
\hline Gene & $\begin{array}{l}\text { Gene type in } \\
\text { PC carcino- } \\
\text { genesis }\end{array}$ & $\begin{array}{l}\text { Chromosomal } \\
\text { location }\end{array}$ & $\begin{array}{l}\text { Type of } \\
\text { mutations }\end{array}$ & Encoded protein & $\begin{array}{l}\text { Frequency } \\
\text { in PCs }\end{array}$ & Encoded protein function(s) & $\begin{array}{c}\text { Molecular and cellular effects } \\
\text { of gene mutations }\end{array}$ \\
\hline $\begin{array}{l}\text { FAT3 } \\
\text { (8) }\end{array}$ & TSG & $11 \mathrm{q} 14.3$ & $\begin{array}{l}\text { Somatic } \\
\text { biallelic } \\
\text { truncating } \\
\text { mutations }\end{array}$ & $\begin{array}{l}\text { FAT Atypical } \\
\text { Cadherin } 3 \text { (FAT3) }\end{array}$ & $\begin{array}{l}11.8 \% \text { of } \\
\text { sporadic PC } \\
\text { (8) }\end{array}$ & $\begin{array}{l}\text { Member of the atypical } \\
\text { cadherin family. The exact } \\
\text { biological functions have not } \\
\text { yet been elucidated. }\end{array}$ & $\begin{array}{l}\text { The biallelic truncating mutations } \\
\text { suggest the loss of a putative } \\
\text { tumor suppressor activity. }\end{array}$ \\
\hline $\begin{array}{l}\text { PIK3CA } \\
(8,11)\end{array}$ & Proto-oncogene & $3 q 26.32$ & $\begin{array}{l}\text { Activating } \\
\text { somatic } \\
\text { missense } \\
\text { mutations }\end{array}$ & $\begin{array}{l}\text { Phosphatidylinositol- } \\
\text { 4,5-Bisphosphate } \\
\text { 3-Kinase Catalytic } \\
\text { Subunit Alpha } \\
\text { (PIK3CA) }\end{array}$ & $\begin{array}{l}12.5 \% \text { of } \\
\text { sporadic PC } \\
\text { (8) }\end{array}$ & $\begin{array}{l}\text { PI3K/AKT/mTOR pathway that } \\
\text { regulates cell signaling } \\
\text { transduction, cell proliferation, } \\
\text { apoptosis, metabolism, and } \\
\text { angiogenesis. }\end{array}$ & $\begin{array}{l}\text { Activating mutations of PIK3CA } \\
\text { activates the PI3K/AKT/mTOR } \\
\text { pathway, resulting in increased } \\
\text { cell proliferation. }\end{array}$ \\
\hline $\begin{array}{l}\text { MTOR } \\
\text { (8) }\end{array}$ & Proto-oncogene & $1 p 36.22$ & $\begin{array}{l}\text { Activating } \\
\text { somatic } \\
\text { missense } \\
\text { mutations }\end{array}$ & $\begin{array}{l}\text { Mechanistic Target } \\
\text { of Rapamycin } \\
\text { Kinase (mTOR) }\end{array}$ & $\begin{array}{l}8.3 \% \text { of } \\
\text { sporadic PC } \\
\text { (8) }\end{array}$ & $\begin{array}{l}\mathrm{PI} 3 \mathrm{~K} / \mathrm{AKT} / \mathrm{mTOR} \text { pathway that } \\
\text { regulates cell signaling } \\
\text { transduction, cell proliferation, } \\
\text { apoptosis, metabolism, and } \\
\text { angiogenesis. }\end{array}$ & $\begin{array}{l}\text { Activating mutations of mTOR } \\
\text { activates the PI3K/AKT/mTOR } \\
\text { pathway, resulting in increased } \\
\text { cell proliferation. }\end{array}$ \\
\hline
\end{tabular}

PCs, Parathyroid Carcinomas; TSG, Tumor Suppressor Gene; LOH, Loss of Heterozygosity; CDK4, cyclin-dependent kinases 4; CDK6, cyclin-dependent kinases 6; PTH, Parathyroid Hormone.

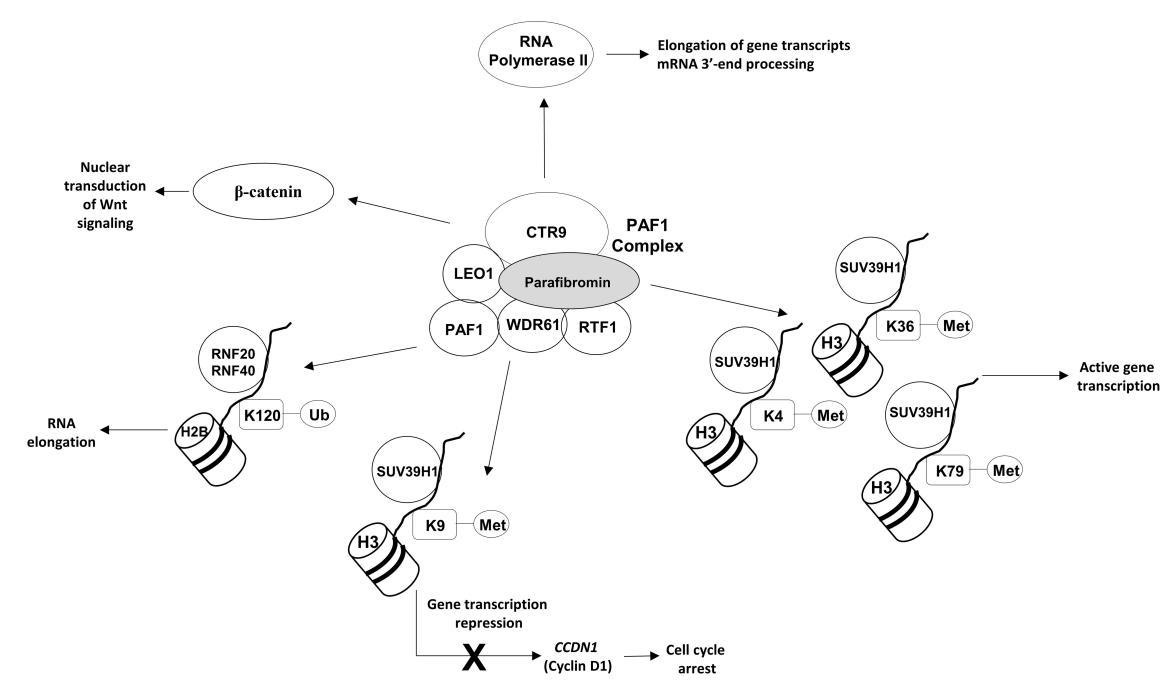

FIGURE 1 | Main roles of parafibromin.

the C-terminal domain of parafibromin, which is deleted in over $80 \%$ of clinically relevant mutations of the CDC73 gene. Loss of parafibromin results in a significant reduction in PAF1 complex binding to RNA polymerase II, in a reduction of Ser2 phosphorylation of the RNA polymerase II CTD, and in shortened poly(A) tails on most cellular transcripts, altering the correct expression of several genes, including genes involved in cell cycle regulation, protein synthesis, and lipid and nucleic acid metabolism (16).

In the absence of parafibromin, replication-dependent histone mRNAs are not cleaved and contain poly(A) tails, being more stable. In sporadic PCs, loss of parafibromin has been associated with over-expression of some members of the replication-dependent histones family, $\mathrm{H} 1.2, \mathrm{H} 2 \mathrm{~A}$ and $\mathrm{H} 2 \mathrm{~B}$, whose genes belong to a histone micro-cluster on chromosome 6p22.2-p21.3 (17). H1.2 inhibits transcription of growth suppressive genes via modulation of chromatin structure (18), thus, the H1.2 increased expression may result in a promotion of cell proliferation.

The PAF1 complex is also involved in multiple aspects of histone modifications (Figure 1). It promotes histone 3 methylations on lysine residues 4, 36 and 79 (H3K4me, $\mathrm{H} 3 \mathrm{~K} 36 \mathrm{me}$ and H3K79me), which are generally associated with transcriptionally active chromatin (16). PAF1 has also been demonstrated to promote histone 3 methylation on lysine 9 (H3K9me) (19) through a direct interaction of the central region of parafibromin (amino acids 128-250) with SUV39H1 histone methyltransferase complex. Amino acids 128-227 have been demonstrated to be the minimal necessary for functional interaction with SUV39H1 (19). PAF1-induced H3K9me results in a transcriptional repression of the CCDN1 gene, encoding cyclin D1, and in a subsequent cell cycle arrest at the 
G1 to S phase transition. Moreover, PAF1 promotes the histone $\mathrm{H} 2 \mathrm{~B}$ mono-ubiquitination on the lysine residue 120 (H2BK120ub1), a histone modification that is positively involved in RNA elongation through a direct interaction with the RNF20/RNF40 ubiquitin-ligase complex (20).

The PAF1 complex has been demonstrated to be an essential regulator of the nuclear transduction of the Wnt signal via a direct protein-protein interaction between parafibromin, LEO1, and $\beta$-catenin. Parafibromin has been shown to directly bind to the $\mathrm{C}$-terminal region of the $\beta$-catenin through the evolutionarily conserved central region of the parafibromin protein (amino acids 218-263), which itself has been found to be sufficient for potent $\beta$-catenin binding (21). The exact role of parafibromin in Wnt signaling has not been clearly established yet, and it might vary by cell type.

Parafibromin is located prevalently in the nucleus, thanks to a nuclear localization signal (amino acids 125-136) and a nucleolar localization signal (amino acids 76-92); loss of one or both of these domains, following $C D C 73$ truncating mutations, prevents the nuclear localization of parafibromin and its main functions, and it has been associated with HPT-JT syndrome $(22,23)$. Loss of parafibromin nuclear immunostaining has been found in PCs and appears to be a distinctive histological feature characterizing malignant tumors from benign parathyroid tumors (24). Both sporadic and HPT-JT-related PCs with biallelic mutation/loss of the CDC73 gene have shown loss of nuclear localization and activity of parafibromin that were strongly associated with tumor malignant behavior, with a younger age of patients and larger tumor size with respect to other CDC73-positive PCs (12). Moreover, PCs negative for parafibromin nuclear immunostaining have shown distinctive morphological (i.e., eosinophilic cytoplasm, very frequent presence of perinuclear cytoplasmic clearing, nuclear atypia, and nuclear enlargement with distinctive coarse chromatin) and proliferative (extensive sheet-like growth rather than acinar architecture) features, which suggest parafibromin-deficient parathyroid malignancies to be a distinct histological and clinical subtype of PCs (12).

\section{CCND1 Gene}

Cyclin D1 is a positive regulator of cell cycle progression that specifically promotes the $\mathrm{G} 1$ to $\mathrm{S}$ phase transition of the cell cycle through the activation of the cyclin-dependent kinases 4 and 6 (CDK4 and CDK6). Cyclin D1 is encoded by the CCND1 protooncogene, located on chromosome 11q13.3. The over-expression of cyclin D1 protein is an extremely common event in parathyroid carcinogenesis, characterizing about $90 \%$ of PCs (7).

A direct pathogenic role of cyclin D1 in parathyroid tumorigenesis has been demonstrated in transgenic mouse models containing a chromosomal rearrangement of the human CCND1 locus, mimicking the one found in two human parathyroid tumors, and over-expressing cyclin D1. As a consequence of cyclin D1 over-expression, mutated mice developed enlarged hyperplastic parathyroid glands, characterized by increased cell proliferation and enhanced PTH secretion, and manifested a chronic PHPT with hypercalcemia and bone abnormalities (25). In these mice, the cyclin D1-induced abnormal parathyroid proliferation temporarily preceded the dysregulation of the calcium-PTH axis, confirming the direct action of up-regulated cyclin D1 on enhancement of parathyroid cell growth, and indicating that the disturbed parathyroid proliferation is the crucial primary initiator leading to the PHPT phenotype (26).

The exact mechanisms responsible for cyclin D1 overexpression in parathyroid carcinogenesis are still largely unclear. As for other types of human cancers, over-expression of cyclin D1 in parathyroid tumor cells presumably derives from gene copy number alterations or chromosomal rearrangements and trans-acting altered regulation of gene expression, rather than activating mutations of the CCDN1 gene. A heterozygote p15-q13 pericentromeric inversion in chromosome 11 was reported in two unrelated cases of benign PAs, positioning the 5 -regulatory element of the PTH gene from the 11 p15 locus directly upstream of the CCDN1 gene on the $11 \mathrm{q} 13$ locus, inducing over-expression of cyclin D1 protein, and, at the same time, maintaining one intact copy of the $P T H$ gene and, thus, the capability to express PTH (27). However, this chromosomal translocation has not been described in PCs. A whole-genome study on sporadic PCs showed somatic amplification of the genomic region containing the CCDN1 gene in $29 \%$ of analyzed cases, $80 \%$ of them being mutually exclusive with cases harboring CDC73 somatic mutations (8), suggesting that $C C D N 1$ amplification is an alternative genetic mechanism to $C D C 73$ inactivation to up-regulate cyclin D1 expression. Since cyclin D1 up-regulation is a frequent event also in benign sporadic PAs (20-40\% of cases), the overexpression of this protein cannot be used as a hallmark to distinguish benign from malignant tumors.

Over-expression of cyclin D1 in mouse fibroblasts has been associated with an enhanced and more rapid cell cycle progression, due to a shortened duration of the G1 phase, and with the induction of anchorage-independent growth and enhanced invasion ability (28). At the molecular level, upregulated cyclin $\mathrm{D} 1$ led to the activation of the $\mathrm{pRB} / \mathrm{E} 2 \mathrm{~F}$ pathway, a pathway that has been shown to be deregulated in a large majority of human tumors, and the consequent increased expression of Fibroblast Growth Factor Receptor 1 (FGFR1), both at the mRNA and protein levels, which presumably acts as a direct mediator of the increased cell invasion of the matrigel in response to treatment with basic Fibroblast Growth Factor (bFGF). These data suggest that the pro-oncogenic action of up-regulated cyclin D1 can be mediated, at least in part, by potentiating the stimulatory effects of $\mathrm{bFGF}$, a pro-proliferation factor that is often produced by stromal cells, on the growth and invasiveness of adjacent tumor cells (28), a mechanism that can also be suspected in parathyroid cancer.

\section{PRUNE Gene}

The Prune Homolog 2 with BCH Domain (PRUNE2) gene was recently identified as a novel PC-associated gene (10). The protein encoded by PRUNE2 gene belongs to the B-cell CLL/ lymphoma 2 and adenovirus E1B $19 \mathrm{kDa}$ interacting family, whose members play roles in many cellular processes, including apoptosis and cell transformation. PRUNE2 protein is a tumor suppressor exerting various biological functions, including the 
suppression of Ras homolog family member A activity, which results in inhibition of oncogenic cellular transformation.

A whole-exome sequencing analysis on PCs showed recurrent mutations of the PRUNE2 gene in $18 \%$ of cases (10). No mutation was detected in the $40 \mathrm{PA}$ validation set, suggesting PRUNE2 gene as a novel candidate gene in malignant carcinogenesis and a possible genetic determinant to diagnose PCs. A germline missense mutation (p.Val452Met) has been identified in a PC sample in absence of CDC73 mutation and with a somatic $\mathrm{LOH}$ at the chromosome 9, containing the PRUNE2 gene. Two somatic nonsense mutations (c.Glu474X and p.Glu537X), presumably inactivating both the two gene alleles, were found in a PC sample bearing a concomitant $C D C 73$ mutation, suggesting a possible synergic effect of these two mutated tumor suppressor genes in determining malignant cancer development. No data were available on the clinical characteristic of that PC, indicating a more severe cancer phenotype as a consequence of the presence of double-gene mutations. These two stop-gain mutations were confirmed as possible causes of PC development by another genomesequencing study, and both were found at somatic levels in one single PC sample, but not in the corresponding normal parathyroid tissue (8). Two somatic missense mutations (p.Gly455Asp and p.Ser450Asn) were identified in two PC cases, both without CDC73 and MEN1 mutations.

All three identified missense mutations were predicted to be probably damaging and likely pathogenic by disrupting the function of the PRUNE2 protein. The two nonsense mutations were predicted to produce a truncated PRUNE2 protein lacking the $\mathrm{BCH}$ domain and, thus, presumably losing the overall tumor suppressor functions, leading to loss of control over cellular transformation. A study by Yu et al. (10) performed a whole-gene sequencing on 8 PCs included in the discovery cohort, localizing all the three identified mutations of the PRUNE2 gene in the exon 8, which appeared to be a possible mutational hot spot. As a consequence, the additional 13 PC samples of the validation cohort were sequenced only for exon 8 , presumably leading to an underestimation of the real PRUNE2 mutation rate in PCs. Whole PRUNE2 gene sequencing on larger and different series of PC patients is needed to confirm PRUNE2 mutations as a genetic cause of malignancy of parathyroid glands and to identify a possible occurrence of mutations in other regions of the gene.

\section{EZH2 Gene}

The Enhancer of Zeste Homolog 2 (EZH2) gene encodes a histone 3 lysine 27 methyltransferase that is a member of the Polycomb Repressive 2 (PCR2) complex. EZH2 gene amplification at 7q36.1 locus is common in PCs (about $60 \%$ of cases), acting as an oncogene in parathyroid carcinogenesis and showing a significant overexpression of EZH2 mRNA and protein in malignant carcinomas compared with adenomas and hyperplastic parathyroid glands (9). Conversely, no EZH2 gene mutations were found in sporadic PCs (29), while a recurrent p.Tyr641Asp missense mutation was identified in unrelated PAs $(30,31)$. Therefore, different types of genetic aberrations of the $E Z H 2$ gene appear to differentially characterize PCs and PAs.

Increased expression and enzymatic activity of EZH2 protein result in an elevated histone trimethylation on lysine 27
(H3K27me3) across the genome, a histone modification that is commonly associated with transcriptional inhibition. A suspected target gene, repressed by EZH2-mediated $\mathrm{H} 3 \mathrm{~K} 27 \mathrm{me} 3$, is the HIC1 tumor suppressor gene, which is normally involved in control of parathyroid growth; an aberrant down-regulation of HIC1 has been observed in both benign and malignant parathyroid, presumably due to the repressive action of H3K27me3 on gene expression (32) (Figure 2).

Normally, EZH2 mediates the epigenetic gene transcription repression of several Wnt antagonists, including the growthsuppressive AXIN2 protein, a negative regulator of cytoplasmatic levels and stability of $\beta$-catenin in the absence of Wnt ligand. As a consequence, an excessive expression of EZH2 represses AXIN2, and it has been demonstrated to significantly contribute to an aberrant accumulation of the transcriptionally active (nonphosphorylated) form of $\beta$-catenin in the cytoplasm and the consequent nuclear translocation, resulting in the nuclear transduction of Wnt signaling that leads to increased cyclin D1 expression and enhanced cell proliferation (9) (Figure 2).

\section{ADCK1 Gene}

In a whole-genome sequencing analysis, a recurrent missense mutation p.Ile482Met in the ADCK1 gene, encoding the AarF Domain-Containing Kinase 1 (ADCK1), was found in 2 of the 17 analyzed PC cases (11.8\%) (8). The role of the ADCK1 protein is not yet clear; it is not known if it has a protein kinase activity or which amino acid residue it would phosphorylate (Ser, Thr or Tyr). The monoallelic somatic ADCK1 mutation suggests a dominant-negative effect of the mutated protein and the $A D C K 1$ gene as a candidate oncogene in PC development.

\section{AKAP9 Gene}

A whole-genome sequencing analysis on 17 sporadic PC samples has identified the AKAP9 gene as recurrently mutated $(3 / 17 ; 17.6 \%$ of analyzed cases) (8). The AKAP9 gene encodes the A-Kinase Anchoring Protein 9 (AKAP9), a member of the A-kinase anchor proteins, that regulates cellular localization and function of the protein kinase A. Two missense and one nonsense somatic mutations were identified in 3 cases, two of them showing the biallelic inactivation of the gene, thus suggesting a tumor suppressor activity of $A K A P 9$ in parathyroids. Further functional investigations are needed to assess the potential role of AKAP9 loss/inactivation as oncogenic driver in PC development.

\section{ZEB1 Gene}

The ZEB1 gene encodes the Zinc Finger E-Box Binding Homeobox 1 (ZEB1) protein, a zinc finger transcription factor that acts as a transcriptional repressor, represses E-cadherin promoter and induces the epithelial-to-mesenchymal transition (EMT), promoting tumor invasion and metastases.

Somatic heterozygote mutations of the ZEB1 gene have been recurrently identified in PC samples (17.6\% of cases analyzed by a whole-genome sequencing) (8). The molecular and cellular effects of the identified ZEB1mutations in PCs have not yet been evaluated, but activating mutations are suspected to promote EMT and consequent tumor invasivity and metastatic capability. 


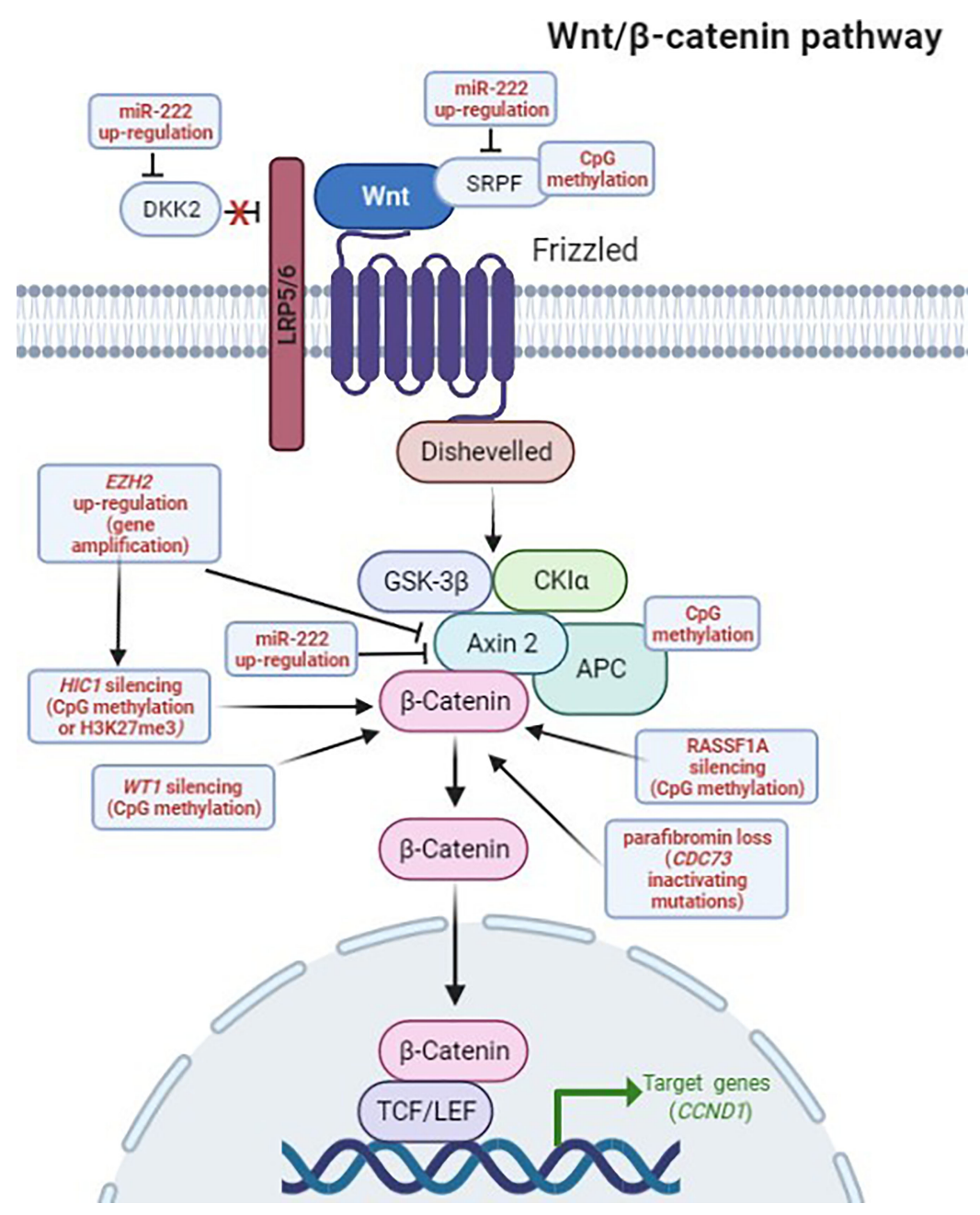

FIGURE 2 | Deregulation of the Wnt/ $\beta$-catenin signaling in PCs. Genetic and epigenetic aberrations detected in PC, altering the Wnt/ $\beta$-catenin pathway, are highlighted in red. In the canonical Wnt/ $\beta$-catenin pathway, the Wnt ligands initiate signaling by interacting, on the cell surface, with the Frizzled (FZD) receptor and the low density lipoprotein receptor-related protein 5/6 (LRP5/6) coreceptor. The ligand-activated FZD-LRP5/6 complex recruits, respectively, Dishevelled and AXIN2 intracellular proteins, preventing the constitutive destruction of cytosolic $\beta$-catenin by disassembling the $\beta$-catenin destruction complex, consisting of AXIN2, adenomatous polyposis coli (APC), glycogen synthase kinase3 $\beta$ (GSK3 $\beta$ ) and casein kinase 1 (CK1), and ultimately leading to active $\beta$-catenin accumulation and nuclear translocation. In the nucleus, $\beta$-catenin binds and activates transcription factors of the lymphoid enhancer-binding factor (LEF)/T-cell factor (TCF) family, leading to the transcription of Wnt target genes (i.e. CCND1). DKK2 and SFRP proteins are natural extracellular inhibitors of the Wnt signaling, by respectively binding, and inactivating, the LRP5/6 coreceptor and the Wht ligands. Figure created in BioRender.com, accessed on 10 January 2022.

\section{FAT3 Gene}

The FAT3 gene has recently been recognized as a possible candidate gene in sporadic PC development by whole-genome profiling (8). This gene encodes the FAT Atypical Cadherin 3 (FAT3) protein, whose biological role has not yet been clearly defined. FAT3 belongs to a family of proteins that includes two known tumor suppressors, FAT1 and FAT4.

Two different somatic nonsense mutations were identified in $2 / 17(11.8 \%)$ analyzed cases, both with the biallelic inactivation of the gene and creating a premature stop codon near to the $\mathrm{N}$ terminal region of the FAT3 protein, suggesting the FAT3 gene as a putative tumor suppressor gene in parathyroid carcinogenesis, possibly regulating the Wnt signaling.

\section{PI3K/AKT/mTOR Signaling Pathway}

The PI3K/AKT/mTOR pathway is an intracellular signaling pathway important for regulating cell signal transduction and biological processes, such as cell proliferation, apoptosis, metabolism, and angiogenesis. Several studies have shown that the deregulation of this signaling pathway is involved in the occurrence and development of different types of human malignancies (33). A genomic profiling of 24 PCs revealed the presence of somatic activating missense variants in genes encoding components of this signaling pathway in $21 \%(5 / 24)$ of cases: p.Lys111Glu, p.Glu545Ala, and p.His1047Arg in the PIK3CA gene, and p.Leu1460Pro and p.Gln2524Leu in the MTOR gene (8). Results from this study suggest the altered 
$\mathrm{PI} 3 \mathrm{~K} / \mathrm{AKT} / \mathrm{mTOR}$ pathway as a major oncogenic factor in parathyroid carcinogenesis.

The somatic activating missense p.Glu545Lys variant of the PIK3CA gene was identified, through a complete genome landscape mutational analysis of tumor specimens, in a primary sporadic PC, but not in the 7 PC recurrences, suggesting a role for mutated PIK3CA protein in tumor initiation, but not in tumor progression and tissue invasion (11).

\section{YAP1 Gene}

The Yes Associated Protein 1 (YAP1) gene encodes a downstream nuclear effector of the Hippo signaling pathway, which is known to play a role in the development and progression of multiple cancers, by acting as a transcriptional regulator of this signaling pathway. Recently Tavanti et al. (34) found a remarkable loss of YAP1 protein nuclear staining in formalin-fixed paraffin-embedded PC specimens, compared with normal parathyroid and PA samples that were both characterized by a positive nuclear expression of YAP1. Loss of YAP1 nuclear localization was independent of CDC73 and MEN1 gene status. No data were reported about YAP1 gene status at both germline and somatic levels in PCs, and the molecular mechanism responsible for loss of YAP1 nuclear localization in PC remains to be fully elucidated.

\section{FLNA Gene}

The filamin A (FLNA) gene encodes the homonym filamin A protein, a non-muscle actin filament cross-linking scaffold protein that influences the intracellular localization of numerous proteins. A very recent study by Storvall et al. (35) found that PCs were characterized by significantly increased cytoplasmic FLNA expression, compared to both PAs and atypical parathyroid adenomas (aPAs), suggesting that the increased cytoplasmic, and membranous, FLNA expression could be a marker of malignancy, and a potential prognostic predictor of aggressive behavior in parathyroid neoplasms, mostly in combination with parafibromin expression. However, a previous study (36) showed opposite results, reporting a decreased expression of full-length FLNA in the cytoplasm of tumoral parathyroid epithelial cells, both for PAs (50\% to 10\% of FLNA-positive cells) and PCs (less than $10 \%$ or totally absent FLNA-positive cells), with respect to the normal parathyroid counterpart.

Therefore, the role of FLNA expression levels in parathyroid carcinogenesis needs to be clearly elucidated by further studies.

\section{TBX1 Gene}

A greater than two-fold reduced expression of the T-Box Transcription Factor 1 (TBX1) gene, with respect to normal parathyroids, was found in $71 \%(10 / 14)$ of human PCs at mRNA level, and confirmed, at the protein level, by in a significant decrease of TBX1-positive immunostained cells (37). Interestingly, in all the 10 PC samples characterized by a reduced number of TBX1expressing cells, this molecular signature was associated with both the downregulation of TBX1 transcript and the loss of parafibromin immunostaining, while the $4 \mathrm{PC}$ samples conserving parafibromin expression had TBX1 mRNA expression levels similar to those of normal parathyroid, suggesting a regulatory relationship between TBX1 and parafibromin, involved in parathyroid carcinogenesis.

\section{EPIGENETICS OF PARATHYROID CARCINOMA}

Epigenetic processes are one of the most important regulators of gene expression and one of the most often deregulated mechanisms in human tumors. Epigenetic mechanisms are heritable but reversible, and they include DNA methylation, histone modifications, and small and long non-coding RNAs.

\section{DNA Methylation in Parathyroid Carcinoma}

DNA methylation consists of the covalent addition of a methyl group at the 5'-position of a cytosine, usually followed by a guanine (CpG dinucleotide). DNA methylation is catalyzed by DNA methyltransferases (DNMTs), while DNA demethylation is promoted by ten-eleven translocation (TET) methylcytosine dioxygenases. CpG dinucleotides are spread out across the genome, being commonly heavily methylated, with the exception of $\mathrm{CpG}$ islands, which are prevalently located in the promoter regions of genes. Global CpG methylation in intergenic regions is a fundamental mechanism to repress the expression of potentially harmful genetic sequences, such as transportable and retroviral elements. The majority of human gene promoters (roughly $70 \%$ ) reside within $\mathrm{CpG}$ islands; the hypermethylation of these $\mathrm{CpG}$ islands is a reversible mechanism of gene silencing, responsible for regulating tissue-specific gene expression.

Human cancers are generally characterized by a global DNA hypomethylation, with respect to their normal counterparts. In contrast, both benign and malignant parathyroid tumors show a global methylation pattern similar to normal parathyroid glands $(38,39)$.

A genome-wide analysis of CpG island methylation identified 367 gene promoters significantly differentially methylated between PAs and normal parathyroids, 175 between PCs and normal parathyroids and 263 between PAs and PCs (40). In-depth analysis of the top 100 differentially methylated $\mathrm{CpG}$ islands showed, in PC samples, the presence of hypermethylation of all the examined sites (40).

Promoter hypermethylations of Adenomatous Polyposis Coli $(A P C)$ and Ras-association Domain Family Member 1A (RASSF1A) tumor suppressor genes are two common epigenetic changes in parathyroid tumors (38-41), which have been interestingly found in the $100 \%$ of analyzed PC samples $(39,41)$ (Table 2). Both silencing of APC and RASSF1A genes lead to the accumulation of the active form of $\beta$-catenin and to the subsequent activation of the canonical Wnt signaling, resulting in transcription of TCF/LEF-responsive target genes, including CCND1.

Hypermethylation of promoters of HIC1, PYCARD, and GATA4 gene has specifically found to characterize PCs, with respect to both normal parathyroid glands and PAs $(32,40)$.

Main hypermethylated gene promoters identified in parathyroid tumors are reported in Table 2.

\section{Histone Modifications in Parathyroid Carcinoma}

Histones are the protein component of chromosomes, exerting a key role in the packing of chromatin and the regulation of gene expression. These proteins undergo post translational modifications, regulated by specific histone-modifying enzymes, consisting in the addition or removal of one or more methyl, acetyl, 
phosphate, or ubiquitin groups to specific amino acid residues. Histone modifications are reversible epigenetic mechanisms that alter chromatin state, modifying the accessibility of transcription factors to the promoters of target genes, thus positively or negatively regulating transcriptional activity.

As described above, one of the most commonly lost tumor suppressors in sporadic and syndromic PCs, the parafibromin, is a key regulator of various histone modifications (Figure 1). Normally, this nuclear tumor repressor interacts with the SUV39H1 histone methyltransferase complex, promoting H3K4me and H3K79me, and with the RNF20/RNF40 ubiquitine ligase complex, promoting H2BK120ubl.

Two other genes, EZH2 (9) and PRDM2/RIZ1 (42), whose expression has been reported to be deregulated in human PCs, respectively by gene amplification and promoter hypermethylation, encode methyl transferases, indicating a role of deregulated histone methylation in parathyroid carcinogenesis.

\section{Deregulated MicroRNAs in Parathyroid Carcinoma}

MicroRNAs (miRNAs) are single-stranded non-coding small RNAs (19-25 nucleotides in length), that negatively regulate the expression of target mRNAs, through a base-pairing mechanism, which leads to transcript endonucleolytic cleavage and degradation, or to transcriptional repression. Over 2,500 different mature human miRNAs have been identified thus far (www.mirbase.org), encoded by about 1,800 genes, which in more than $50 \%$ of cases are assembled in genomic clusters, rather than being casually distributed along the genome.

Deregulation of miRNA expression/activity has been found in many types of human cancers, acting as oncogene (oncomiR) or tumor suppressors; tumor cells show a larger alteration of miRNA expression compared to their normal counterparts.

Interestingly, deregulated signatures in miRNA expression appear to specifically characterize PCs, compared to both PAs and normal parathyroid glands, suggesting the possibility of using these epigenetic changes as markers to distinguish different parathyroid tumor types. PCs show a miRNA global downregulation (about $80 \%$ ) with respect to normal parathyroids. The most significantly down-regulated miRNAs in PCs were miR-26b (44), miR-30b (44), miR-126-5p (44), and miR-296-5p (45), while significantly up-regulated miRNAs were miR-222 (45), miR-517c (46), and miR-503 (45). Conversely, miR-139-3p resulted similarly expressed in PCs and PAs, and significantly down-regulated in both parathyroid tumor types compared to healthy glands (45).

Deregulated miRNAs specifically characterizing PC, and their possible role in carcinogenesis, are reported in Table 3.

Among deregulated miRNAs, miR-517c, located within the C19MC miRNA cluster at 19q13.42, showed the most significant expression difference between PC and PA, and its expression in PA was similar to that observed in normal parathyroids, strongly suggesting this miRNA as a potential diagnostic biomarker of PC, and potentially involved in determining the malignant phenotype. In PC samples, the up-regulation of miR-517c significantly correlated with over-expression of miR-371 and miR-372, two miRNAs of the miR-371-373 cluster, closely distal to C19MC. Deregulated expression profiles of miR-517c, miR-371, and miR-372, observed in primary PC, were conserved in their matched metastases (46).
Considering clinical features of PC patients, expression levels of miR$517 \mathrm{c}$ in PC samples positively correlated with serum values of calcium and PTH, and with tumor weight (46). MiR-517c showed a tumor suppressor activity in human glioblastoma (49) and hepatocellular carcinoma cells (50), respectively through the inhibition of the epithelial-to-mesenchymal-like transition phenotype by targeting KPNA2 mRNA and, thus, disrupting the TP53 nuclear translocation, and through the inhibition of cell proliferation by targeting PTK2B/Pyk2 mRNA. Conversely, in PC, miR-517c appears to act as a proto-oncogene, although the pro-oncogenic effect of miR$517 \mathrm{c}$ up-regulation and the target $\mathrm{mRNA}(\mathrm{s})$ in parathyroid glands are not yet known.

Down-regulation of miR-296-5p showed a valuable predictive value in distinguishing PCs from healthy parathyroids (45); this miRNA was also down-regulated in a lung metastasis from a primary PC (46). MiR-296-5p is located at the imprinted complex locus GNAS (encoding the alpha subunit $S$ of the guanine nucleotidebinding protein) on chromosome $20 \mathrm{q} 13$ and is expressed from the paternally-inherited allele (GNAS antisense RNA1; GNAS-AS1), but not from the maternally-derived allele (51). Interestingly, downregulation of miR-296-5p seems to be restricted to PC, and it has not yet been reported in other human malignancies, indicating this miRNA as a possible parathyroid tissue-specific tumor suppressor. The putative mRNA target of miR-296-5p, the Hepatocyte Growth Factor-Regulated Tyrosine Kinase Substrate (HGS), which has been found to be over-expressed in PC samples with down-regulated miR296-5p, is involved in the Wnt pathway, which is often altered in parathyroid tumors, suggesting a pro-oncogenic role of HGS upregulation in parathyroid glands via Wnt signaling.

Interestingly, miR-222 was shown to suppress the expression of multiple negative regulators of the $\mathrm{Wnt} / \beta$-catenin pathway, including DKK2, WIF2, SFRP2 and AXIN2 (Figure 2) (52). This miRNA is over-expressed in the majority of epithelial tumors, where it decreases the expression of epithelial-specific genes and increases the expression of mesenchymal-specific genes, promoting the epithelial-to-mesenchymal transition, and cell migration.

\section{Deregulated Long Non-Coding RNAs in Parathyroid Carcinoma}

Long non-coding RNAs (lncRNAs) are non-coding transcripts, longer than 200 nucleotides, acting as epigenetic regulators of gene expression, mainly in a tissue-specific fashion. A role of these molecules in regulating chromatin modifications and transcriptional and posttranscriptional gene expression has been demonstrated (53), as well as the fact that lncRNA deregulation is strongly associated with human tumorigenesis and cancer progression, through the activation of prooncogenic pathways and crosstalk with other RNA subtypes and epigenetic mechanisms (48). Alterations in lncRNA expression have been associated with endocrine diseases (54) and cancers $(55,56)$, including endocrine malignancies (57).

Up-regulation of two IncRNAs, [lncRNA PVT1 (47) and lncRNA BC200 (48)], and down-regulation of IncRNA GLIS2-AS1 (55), were significantly associated with PCs compared to healthy tissue and PAs. LncRNA BC200 has also been shown to discriminate PCs from aPAs, appearing to be a specific molecular signature of malignant tumors (48). Interestingly, IncRNA BC200 resulted significantly upregulated in the group of PCs with CDC73 mutations compared to that of PCs 
TABLE 2 | Hypermethylated gene promoters in parathyroid tumors compared to normal parathyroid tissue.

\begin{tabular}{|c|c|c|c|c|}
\hline \multicolumn{5}{|c|}{ Hypermethylated gene promoters in parathyroid carcinomas } \\
\hline Gene & $\begin{array}{l}\text { Encoded } \\
\text { protein }\end{array}$ & Encoded protein function(s) & $\begin{array}{l}\text { Frequency } \\
\text { in PCs }\end{array}$ & $\begin{array}{l}\text { Molecular and cellular effects of } \\
\text { promoter hypermethylation-driven } \\
\text { gene silencing }\end{array}$ \\
\hline HIC1 (32) & $\begin{array}{l}\text { HIC ZBTB } \\
\text { Transcriptional } \\
\text { Repressor } 1 \\
\text { (HIC1) }\end{array}$ & $\begin{array}{l}\text { Transcription repressor that inhibits expression of E2 transcription factor } 1 \\
\text { (E2F1) by directly binding its promoter, and positively modulates p53 function } \\
\text { by repressing transcription of the } \\
\text { deacetylase SIRT1 that can inactivate p53 by deacetylation. } \\
\text { HIC1 negatively regulates the Wnt pathway and the TCF-mediated gene } \\
\text { transcription by directly binding TCF } 4 \text { and } \beta \text {-catenin and preventing them from } \\
\text { binding to the promoters of the TCF-responsive genes. }\end{array}$ & $\begin{array}{l}100 \%(5 / 5) \\
\text { of sporadic } \\
\text { PCs }(32)\end{array}$ & $\begin{array}{l}\text { Silencing of the HIC gene may result in: } \\
\text { - reduction/loss of p53 tumor } \\
\text { suppressor activity; } \\
\text { - activation of the canonical Wnt/ } \beta \text { - } \\
\text { catenin pathway with transcription of } \\
\text { TCF-responsive genes (Figure 2). }\end{array}$ \\
\hline $\begin{array}{l}\text { PYCARD } \\
(40)\end{array}$ & $\begin{array}{l}\text { PYD and CARD } \\
\text { Domain } \\
\text { Containing } \\
\text { (PYCARD) }\end{array}$ & $\begin{array}{l}\text { PYCARD is an adaptor protein, composed of two protein-protein interaction } \\
\text { domains, that mediates assembly of large signaling complexes in apoptotic } \\
\text { signaling pathways via the activation of caspase. }\end{array}$ & $\begin{array}{l}\text { Not } \\
\text { reported }\end{array}$ & $\begin{array}{l}\text { Silencing of the PYCARD gene may play } \\
\text { an important role in escaping from } \\
\text { apoptosis in parathyroid carcinogenesis. }\end{array}$ \\
\hline $\begin{array}{l}\text { GATA4 } \\
(40)\end{array}$ & $\begin{array}{l}\text { GATA Binding } \\
\text { Protein } 4 \\
\text { (GATA4) }\end{array}$ & $\begin{array}{l}\text { GATA4 is a zinc-finger transcription factor that recognizes and binds the GATA } \\
\text { motif present in the promoters of many genes, regulating gene expression. }\end{array}$ & $\begin{array}{l}\text { Not } \\
\text { reported }\end{array}$ & $\begin{array}{l}\text { Not defined in parathyroid } \\
\text { tumorigenesis. }\end{array}$ \\
\hline
\end{tabular}

Hypermethylated gene promoters both in parathyroid carcinomas and parathyroid adenomas.

\begin{tabular}{|c|c|c|c|c|c|}
\hline Gene & $\begin{array}{l}\text { Encoded } \\
\text { protein }\end{array}$ & Encoded protein function(s) & $\begin{array}{l}\text { Frequency } \\
\text { in PCs }\end{array}$ & $\begin{array}{l}\text { Frequency } \\
\text { in PAs }\end{array}$ & $\begin{array}{l}\text { Molecular and cellular effects of promoter } \\
\text { hypermethylation-driven gene silencing }\end{array}$ \\
\hline $\begin{array}{l}\text { RASSF1A } \\
(38,39)\end{array}$ & $\begin{array}{l}\text { Ras } \\
\text { Association } \\
\text { Domain Family } \\
\text { Member } 1 \\
\text { (RASSF1A) }\end{array}$ & $\begin{array}{l}\text { A tumor suppressor gene suspected to } \\
\text { regulate cell proliferation and apoptosis. }\end{array}$ & $\begin{array}{l}100 \%(3 / 3) \\
\text { of sporadic } \\
\text { PCs }(39)\end{array}$ & $\begin{array}{l}98 \%(54 / \\
55) \text { of } \\
\text { sporadic } \\
\text { PAs (38) } \\
52 \%(34 / \\
66) \text { of } \\
\text { sporadic } \\
\text { Pas (38) }\end{array}$ & $\begin{array}{l}\text { Silencing of the RASSF1 gene leads to } \beta \text {-catenin accumulation, } \\
\text { activation of Wnt-regulated gene transcription and enhanced } \\
\text { cell growth (Figure 2). }\end{array}$ \\
\hline$A P C(39)$ & $\begin{array}{l}\text { Adenomatous } \\
\text { Polyposis Coli } \\
\text { Protein (APC) }\end{array}$ & $\begin{array}{l}\text { APC is a tumor suppressor acting as a } \\
\text { negative regulator of the canonical Wnt } \\
\text { signaling pathway by promoting degradation } \\
\text { of } \beta \text {-catenin. }\end{array}$ & $\begin{array}{l}100(5 / 5) \text { of } \\
\text { sporadic } \\
\text { PCs }(41)\end{array}$ & $\begin{array}{l}56 \%(37 / \\
66) \text { of } \\
\text { sporadic } \\
\text { Pas (39) }\end{array}$ & $\begin{array}{l}\text { Silencing of the APC gene leads to deregulated activation of the } \\
\text { canonical Wnt/ } \beta \text {-catenin pathway and enhanced cell growth } \\
\text { (Figure 2). } \\
\text { Treatment of a primary PC cell culture with a DNA } \\
\text { hypomethylating agent (decitabine) restored APC expression, } \\
\text { reduced active non-phosphorylated } \beta \text {-catenin, inhibited cell } \\
\text { growth, and induced apoptosis, confirming the role of APC } \\
\text { promoter hypermethylation in promoting an aberrant cell growth } \\
\text { in the parathyroids (41). }\end{array}$ \\
\hline $\begin{array}{l}\text { SFRP1 } \\
(40)\end{array}$ & $\begin{array}{l}\text { Secreted } \\
\text { Frizzled } \\
\text { Related } \\
\text { Protein } 1 \\
\text { (SFRP1) }\end{array}$ & Inhibitor of the $W n t / \beta$-catenin pathway. & $\begin{array}{l}\text { Not } \\
\text { reported }\end{array}$ & $\begin{array}{l}\text { Not } \\
\text { reported }\end{array}$ & $\begin{array}{l}\text { Epigenetic silencing of SFRP genes leads to deregulated } \\
\text { activation of the canonical Wnt/ } \beta \text {-catenin pathway, which is } \\
\text { associated with cancer (Figure 2). }\end{array}$ \\
\hline $\begin{array}{l}\text { SFRP2 } \\
(40)\end{array}$ & $\begin{array}{l}\text { Secreted } \\
\text { Frizzled } \\
\text { Related } \\
\text { Protein } 2 \\
\text { (SFRP2) }\end{array}$ & Inhibitor of the $W n t / \beta$-catenin pathway. & $\begin{array}{l}\text { Not } \\
\text { reported }\end{array}$ & $\begin{array}{l}\text { Not } \\
\text { reported }\end{array}$ & $\begin{array}{l}\text { Epigenetic silencing of SFRP genes leads to deregulated } \\
\text { activation of the canonical Wnt/ } \beta \text {-catenin pathway, which is } \\
\text { associated with cancer (Figure 2). }\end{array}$ \\
\hline $\begin{array}{l}\text { SFRP4 } \\
(40)\end{array}$ & $\begin{array}{l}\text { Secreted } \\
\text { Frizzled } \\
\text { Related } \\
\text { Protein } 4 \\
\text { (SFRP4) }\end{array}$ & Inhibitor of the $W n t / \beta$-catenin pathway. & $\begin{array}{l}\text { Not } \\
\text { reported }\end{array}$ & $\begin{array}{l}\text { Not } \\
\text { reported }\end{array}$ & $\begin{array}{l}\text { Epigenetic silencing of SFRP genes leads to deregulated } \\
\text { activation of the canonical Wnt/ } \beta \text {-catenin pathway, which is } \\
\text { associated with cancer (Figure 2). }\end{array}$ \\
\hline $\begin{array}{l}\text { CDKN2B } \\
(40)\end{array}$ & $\begin{array}{l}\text { Cyclin } \\
\text { Dependent } \\
\text { Kinase } \\
\text { Inhibitor 2B } \\
\left(\mathrm{p} 15^{\mathrm{INK} 4 \mathrm{~b}}\right)\end{array}$ & $\begin{array}{l}\mathrm{p} 15^{\mathrm{INK} 4 \mathrm{~b}} \text { is a cyclin-dependent kinase } \\
\text { inhibitor, which forms a complex with CDK4 } \\
\text { or CDK6 and prevents the activation of the } \\
\text { CDK kinases, acting as a negative regulator } \\
\text { of cell growth by inhibiting cell cycle G1 } \\
\text { progression. }\end{array}$ & $\begin{array}{l}\text { Not } \\
\text { reported }\end{array}$ & $\begin{array}{l}\text { Not } \\
\text { reported }\end{array}$ & Silencing of the CDKN2B gene increases cell proliferation. \\
\hline
\end{tabular}


TABLE 2 | Continued

\begin{tabular}{|c|c|c|c|c|c|}
\hline WT1 (40) & $\begin{array}{l}\text { Wilms Tumor } \\
\text { Protein (WT1) }\end{array}$ & $\begin{array}{l}\text { WT1 is a transcription factor that plays an } \\
\text { important role in cell development and cell } \\
\text { survival. }\end{array}$ & $\begin{array}{l}\text { Not } \\
\text { reported }\end{array}$ & $\begin{array}{l}\text { Not } \\
\text { reported }\end{array}$ & $\begin{array}{l}\text { Silencing of the WT1 gene eliminates its tumor suppressor } \\
\text { activity. }\end{array}$ \\
\hline $\begin{array}{l}\text { PRDM2/ } \\
\text { RIZ1 (42) }\end{array}$ & $\begin{array}{l}\text { PR/SET } \\
\text { Domain } 2 \\
\text { (PRDM2) }\end{array}$ & $\begin{array}{l}\text { PRDM2 is a zinc-finger protein, member of a } \\
\text { nuclear histone/protein methyltransferase } \\
\text { superfamily, which plays a role in } \\
\text { transcriptional regulation. }\end{array}$ & $\begin{array}{l}100 \%(1 / 1) \\
(42)\end{array}$ & $\begin{array}{l}40 \%(15 / \\
38)(42)\end{array}$ & $\begin{array}{l}\text { Silencing of the } P R D M 2 / R I Z 1 \text { gene is suspected to eliminate its } \\
\text { tumor suppressor activity. }\end{array}$ \\
\hline
\end{tabular}

Hypermethylated gene promoters in parathyroid adenomas.

\begin{tabular}{|c|c|c|c|c|}
\hline Gene & $\begin{array}{l}\text { Encoded } \\
\text { protein }\end{array}$ & Encoded protein function(s) & $\begin{array}{l}\text { Frequency } \\
\text { in PAs }\end{array}$ & $\begin{array}{l}\text { Molecular and cellular effects of promoter } \\
\text { hypermethylation-driven gene silencing }\end{array}$ \\
\hline $\begin{array}{l}\text { CTNNB1 } \\
(39)\end{array}$ & $\beta$-catenin & $\begin{array}{l}\beta \text {-catenin is a key downstream component of the } \\
\text { canonical Wnt signaling pathway. }\end{array}$ & $\begin{array}{l}29 \% \text { (19/ } \\
66) \text { of } \\
\text { sporadic } \\
\text { Pas (39) }\end{array}$ & Not defined in parathyroid tumorigenesis. \\
\hline $\begin{array}{l}P A \times 1 \\
(43)\end{array}$ & $\begin{array}{l}\text { Paired Box } 1 \\
\text { (PAX1) }\end{array}$ & $\begin{array}{l}\text { PAX1 is a transcription factor with a suspected tumor } \\
\text { suppressor activity. }\end{array}$ & $\begin{array}{l}35 \%(14 / \\
40) \text { of } \\
\text { sporadic } \\
\text { Pas (43) }\end{array}$ & $\begin{array}{l}\text { Silencing of the PAX1 gene is suspected to eliminate its tumor } \\
\text { suppressor activity. }\end{array}$ \\
\hline
\end{tabular}

PCs, Parathyroid Carcinomas; PAs, Parathyroid Adenomas.

with wild type parafibromin, in association with more aggressive clinical features, such as higher levels of PTH and calcium ion (48). Over-expression of lncRNA BC200 has been reported in a broad spectrum of tumor cells, being responsible for cell viability, invasion, and migration (58).

lncRNA PVT1 has been shown to promote cell proliferation of nonsmall cell lung cancer through the epigenetic regulation of the large tumor suppressor kinase 2 (LATS2) expression (59), by directly binding to EZH2, a transcriptional repression factor that has been shown to act as a pro-oncogenic factor in parathyroid carcinogenesis (9).

To date, there are no reports in cancer or other human diseases regarding lncRNA GLIS2-AS1, and the biological function of this lncRNA is still unknown. A possible parathyroid tissue-specific tumor suppressor activity could be considered and remains to be investigated.

\section{Circular RNA Expression Profile in Parathyroid Carcinoma}

Circular RNAs (circRNAs) are a recently identified class of singlestrand non-coding RNAs, consisting in a covalently closed loop generated by the 3' and 5' ends of the RNA molecule that have been joined together, which modulate miRNA activity by acting as miRNA sponges, regulate alternative splicing, and are suspected to have a role in human diseases and tumor progression. A microarray-based analysis of circRNA expression profile has been recently performed, for the first time, in human PAs, PCs and healthy parathyroids (60). Selected differentially expressed circRNAs and their corresponding mRNAs were validated by RT-qPCR, showing that 4 circRNAs (circRNA_0035563, circRNA_0017545, circRNA_0001687 and circRNA_0075005) and 4 mRNAs (MYC, FSCN1, ANXA2 and AKR1C3) were all significantly up-regulated in PCs than PAs, with circRNA_0075005 appearing the most promising diagnostic marker for distinguishing PC from PA. Expression of circ_0035563 and circ_0075005 was furtherly validated in formalin-fixed paraffin-embedded samples of PC and PA by fluorescence in situ hybridization, confirming both these molecules to be significantly higher in PC than in benign lesions. In addition, the study found circ_0035563 as significantly related to CDC73 mutations and malignant recurrence, suggesting this parameter as a suitable marker of prognosis in PC patients. Results of this pivotal study open to the possibility of using circRNA expression as marker for the differential diagnosis of PC and PA; the effective clinical value of these molecules needs to be confirmed in further studies on larger sample size from multiple centers, to be analyzed in association with histopathological and clinical features of tumors, and to be functionally studied on PC cell lines.

\section{GENE EXPRESSION PROFILE AND PROTEOMIC ANALYSIS IN PARATHYROID CARCINOMA}

Given the lack of specific PC biomarkers in clinical practice, two recent studies have investigated: 1) gene expression profile (61), 
TABLE 3 | Deregulated miRNAs and IncRNAs in parathyroid carcinomas.

\begin{tabular}{|c|c|c|c|c|}
\hline \multicolumn{5}{|c|}{ Deregulated miRNAs in parathyroid carcinomas } \\
\hline $\begin{array}{l}\text { miRNA } \\
\text { [reference] }\end{array}$ & $\begin{array}{l}\text { Variation } \\
\text { in PCs }\end{array}$ & $\begin{array}{l}\text { Target } \\
\text { mRNA } \\
\text { (s) }\end{array}$ & Biological function of targeted mRNA(s) & Effect of miRNA deregulation in PCs \\
\hline $\begin{array}{l}\operatorname{miR}-26 b \\
(44)\end{array}$ & $\begin{array}{l}\text { Down- } \\
\text { regulated }\end{array}$ & PTEN & $\begin{array}{l}\text { The PTEN gene is a tumor suppressor encoding the } \\
\text { phosphatidylinositol-3,4,5-trisphosphate 3-phosphatase protein } \\
\text { (PTEN), which negatively regulates the intracellular levels of } \\
\text { phosphatidylinositol-3,4,5-trisphosphate and the AKT/PKB pathway, } \\
\text { involved in promoting cell survival and growth in response to } \\
\text { extracellular signals. }\end{array}$ & No studies available. \\
\hline $\begin{array}{l}\operatorname{miR}-30 b \\
(44)\end{array}$ & $\begin{array}{l}\text { Down- } \\
\text { regulated }\end{array}$ & TRIM27 & $\begin{array}{l}\text { Tripartite motif-containing } 27 \text { (TRIM27) is a component of the } \\
\text { TRIM27-PI3K/Akt axis, involved in various malignant tumor processes, } \\
\text { such as promotion of cell proliferation, inhibition of apoptosis, and } \\
\text { facilitation of cell invasion and metastases. } \\
\text { TRIM27 has been shown to function as an oncogene by activating } \\
\text { epithelial-mesenchymal cell transition and its up-regulation has been } \\
\text { associated with tumor invasion, metastasis and prognosis. }\end{array}$ & No studies available \\
\hline $\begin{array}{l}\operatorname{miR}-126-5 p \\
(44)\end{array}$ & $\begin{array}{l}\text { Down- } \\
\text { regulated }\end{array}$ & EGFL7 & $\begin{array}{l}\text { The EGFL } 7 \text { gene encodes the epidermal growth factor-like domain } 7 \\
\text { (EGFL7) protein that is involved in cellular migration and angiogenesis. }\end{array}$ & No studies available. \\
\hline $\begin{array}{l}\text { miR-296-5p } \\
(45)\end{array}$ & $\begin{array}{l}\text { Down- } \\
\text { regulated }\end{array}$ & HGS & $\begin{array}{l}\text { The encoded HSG protein plays a critical role in degradation and } \\
\text { recycling of membrane receptors by sorting monoubiquitinated } \\
\text { membrane proteins into exosomes and targeting them for lysosome- } \\
\text { dependent degradation. }\end{array}$ & $\begin{array}{l}\text { In human PC samples, the down-regulation of miR-296- } \\
5 p \text { resulted in increased HGS mRNA levels. A dramatic } \\
\text { immunostaining-detected over-expression of HGS protein } \\
\text { was observed in PCs, compared with both PAs and } \\
\text { normal glands (45). }\end{array}$ \\
\hline $\begin{array}{l}\operatorname{miR}-222 \\
(45)\end{array}$ & $\begin{array}{l}\text { Up- } \\
\text { regulated }\end{array}$ & CDKN1B & $\begin{array}{l}\text { The CDKN1B gene encodes the } \mathrm{p} 27^{/ \mathrm{kip} 1} \text { protein, a cyclin-dependent } \\
\text { kinase inhibitor, which negatively regulates cell cycle progression and } \\
\text { cell growth. }\end{array}$ & $\begin{array}{l}\text { In human PC samples, the over-expression of miR-222 } \\
\text { resulted in almost complete loss of expression and } \\
\text { nuclear localization of the p } 27^{/ \text {kip1 }} \text { protein (45). }\end{array}$ \\
\hline $\begin{array}{l}\operatorname{miR}-517 c \\
(46)\end{array}$ & $\begin{array}{l}\text { Up- } \\
\text { regulated }\end{array}$ & $\begin{array}{l}\text { Still } \\
\text { unknown }\end{array}$ & Non applicable. & No studies available. \\
\hline $\begin{array}{l}\operatorname{miR}-503 \\
(45)\end{array}$ & $\begin{array}{l}\text { Up- } \\
\text { regulated }\end{array}$ & CCDN1 & $\begin{array}{l}\text { The CCDN1 gene encodes cyclin D1, a positive regulator of cell cycle } \\
\text { progression that promotes the G1 to } S \text { phase transition through } \\
\text { activation of CDK4 and CDK6. }\end{array}$ & $\begin{array}{l}\text { In human PC samples with up-regulation of miR-503, } \\
\text { cyclin D1 displayed a heterogeneous immunoreactivity } \\
\text { (42). High levels of cyclin D1 were also found in a subset } \\
\text { of PAs, seeming to exclude miR-503 as a main modulator } \\
\text { of cyclin D1 expression in parathyroid cells. }\end{array}$ \\
\hline
\end{tabular}

\begin{tabular}{|c|c|c|c|}
\hline LncRNA & $\begin{array}{l}\text { Variation } \\
\text { in PC }\end{array}$ & Biological function of IncRNA & Effects of IncRNA deregulation in PC \\
\hline $\begin{array}{l}\text { IncRNA } \\
\text { GLIS2-AS1 } \\
(47)\end{array}$ & $\begin{array}{l}\text { Down- } \\
\text { regulated }\end{array}$ & Still unknown & No studies available. \\
\hline $\begin{array}{l}\text { IncRNA } \\
\text { PVT1 (47) }\end{array}$ & $\begin{array}{l}\text { Up- } \\
\text { regulated }\end{array}$ & $\begin{array}{l}\text { The PVT1 gene has been identified as a candidate oncogene. Increased copy } \\
\text { number and over-expression of this gene have been associated with many types } \\
\text { of human cancers. }\end{array}$ & No studies available. \\
\hline $\begin{array}{l}\text { IncRNA } \\
\text { BC200 (48) }\end{array}$ & $\begin{array}{l}\text { Up- } \\
\text { regulated }\end{array}$ & $\begin{array}{l}\text { IncRNA BC200 is a protein-interacting non-coding RNA, presumably involved in } \\
\text { the regulation of translation repression. }\end{array}$ & No studies available. \\
\hline
\end{tabular}

PC, Parathyroid Carcinoma; PA, Parathyroid Adenoma.

and 2) global proteomic expression pattern (62), as possible molecular signatures to distinguish PC from PA.

The first study (61) compared the expression of 740 genes, known to be involved in main cancer progression processes [angiogenesis, extracellular matrix (ECM) remodeling, EMT, metastasis], between PAs, non-metastatic PCs, and metastatic PCs, identifying differentially expressed groups of genes able to discriminate PAs from PCs, and also differentiate non-metastatic PCs from metastatic PCs. Two specific signatures of 87 gene expressions (43 up-regulated and 44 down-regulated) and of 103 gene expressions (65 up-regulated and 38 down-regulated) characterized non-metastatic PCs and metastatic PCs, respectively, with respect to PAs. Among genes showing upregulation in both metastatic and non-metastatic PCs vs PAs, there were genes encoding components of the ECM (COL1A1, COL1A2, COL3A1, COL5A2, FN1, LUM, LOX, THBS1, THBS2, $B G N$, and SFRP2) and genes encoding enzymes involved in proteolysis, cross-linking and assembly processes of proteins of the ECM (FAP, LOX, SULF1 and PXDN), suggesting a key role of ECM deregulation in carcinogenesis, presumably altering cell proliferation (61). Metastatic PCs showed a significant upregulation of MMP9, SOX2, CD24, BMP7, ANGPTL4, and FGFR1 genes, and a down-regulation of ERBB3, TBX1, RAB25, and $F B P 1$ genes, compared to both PAs and non-metastatic PCs, 
suggesting a role of this gene expression signature in tumor progression and metastatic spread (61).

The second study (62) compared the global proteomic profile between a PC and a PA, co-existing in the same patient, by using twodimensional differential gel electrophoresis coupled with mass spectrometry. The possibility to compare the two different types of tumors from the same patient allowed the identification of distinctive PC protein features without any external confounding influences, such as age, sex, germline background, lifestyle, and environmental factors. PC showed the specific over-expression of 23 proteins and the specific under-expression of 10 proteins, mainly belonging to specific biological processes, such as cell metabolism, cell signaling, and protein ubiquitination. In particular, the Ubiquitin C-terminal Hydrolase L1 (UCH-L1), a member of the deubiquitinase family involved in processing ubiquitin precursors and in regulating angiogenesis (63), and whose up-regulation has previously been demonstrated to enhance cell invasion/metastasis $(64,65)$, and increase multidrug resistance in breast cancer $(66,67)$, resulted highly over-expressed in PC, suggesting an oncogenic role of this protein in the malignant carcinogenesis of parathyroid tissue and, at the same time, indicating UCH-L1 as a possible distinctive immunohistochemical signature of PC with respect to benign parathyroid tumors. Other promising protein biomarkers, all overexpressed in PCs, were: Malate Dehydrogenase 1 (MDH1), an enzyme that catalyzes the NAD/NADH-dependent reversible oxidation of malate to oxaloacetate in many metabolic pathways and was showed to be up-regulated in cancer (68); Chloride Intracellular Channel Protein 1 (CLIC1), a protein involved in regulating cell proliferation and differentiation, and metastasis (69, 70), and whose up-regulation has previously been associated with human malignancies; and Superoxide Dismutase 2 (SOD2), which is a key player of the antioxidant system of the cell and whose increased expression appears correlated to the stage of tumor progression (71).

\section{CONCLUDING REMARKS}

- Pre-operative diagnosis of PCs is complicated. There are no specific histological and molecular features helping to preoperatively distinguish PAs, aPAs, and PCs.

- Loss-of-function mutations and/or loss of the CDC73 tumor suppressor gene are the main genetic defects in PCs, both in the sporadic form and in the context of FIPH or HPT-JT syndrome. However, the absence of nuclear staining for parafibromin in tumor samples is not sufficient, alone, for a histological diagnosis of PCs.

- Hypermethylation of specific gene promoters has been specifically associated with PC, leading to gene silencing and presumably triggering parathyroid carcinogenesis. Theoretically, treatment with inhibitors of DNA methyltransferase would be expected to reduce the methylation density at hypermethylated promoters, restoring the normal expression of silenced genes. However, the anti-oncogenic beneficial of these molecules is controversial, since they exert a non-specific cytosine demethylation action that cannot be specifically directed on the target hypermethylated promoters. This may lead to a global DNA hypomethylation, increasing the risk of DNA damages.
- Deregulation of expression of specific miRNAs showed a promising capability to discriminate parathyroid tumors from healthy glands, as well as among different types of parathyroid tumors. MiRNA signatures specifically characterizing PCs have been identified.

- Down-regulation of miR-296-5p and miR-126-5p and upregulation of miR-517c appear to be valuable molecular discriminators between PCs and PAs. These molecules might be, thus, valuable molecular targets for epigenetic therapy of PCs.

- Target inhibition of up-regulated miRNAs having an oncogenic activity (oncomiR) may be a valuable approach for epigenetic therapy of PC, which can be easily obtained by small molecule miRNA inhibitors, miRNA sponges, miRNA masks, or synthetic, modified antisense anti-miRNAs.

- The deregulated expression of specific lncRNAs (lncRNA PVT1, lncRNA GLIS2-SA1, and lncRNA BC200) also appears to characterize molecular signatures of human PCs, distinguishing between benign and malignant parathyroid tumors. However, the real contribution of lncRNAs to parathyroid carcinogenesis remains to be fully elucidated.

- The interplay between different epigenetic mechanisms, and their possible synergic action in promoting parathyroid carcinogenesis, should be studied as well.

- Epigenetic deregulation, rewiring the cell translational network, is thought to initiate PC tumorigenesis, by inducing a dedifferentiated tumor phenotype, characterized by an "embryonic-like" gene expression signature. Mutated oncogenes and tumor suppressor genes are suspected to contribute to parathyroid cancer development, presumably not only by inducing an increased cell proliferation, but also because of their role in deregulating the cell epigenome.

- Further investigations, to identify and/or confirm deregulated epigenetic factors specifically characterizing PCs, are needed, in association with functional in vitro studies, to understand their role in PC initiation, development and progression. The highthroughput "omic" technologies (genomics, transcriptomics, proteomics, metabolomics) will allow collective quantification and characterization of wide numbers of biological molecules, at different molecular levels, helping in deciphering the regulatory networks, whose deregulation underlies the development and progression of parathyroid cancer, and in identifying novel therapeutic targets.

\section{AUTHOR CONTRIBUTIONS}

FM wrote the manuscript and drew tables and figure. FG and $\mathrm{GPa}$ performed the review of published literature and contributed to drawing tables and figure. GPe, RS, and MB critically reviewed the manuscript. All authors contributed to the article and approved the submitted version.

\section{ACKNOWLEDGMENTS}

Authors are grateful to the F.I.R.M.O. Foundation for the support. 


\section{REFERENCES}

1. Cetani F, Marcocci C, Torregrossa L, Pardi E. Atypical Parathyroid Adenomas: Challenging Lesions in the Differential Diagnosis of Endocrine Tumors. Endocr Relat Cancer (2019) 26(7):R441-64. doi: 10.1530/ERC-19-0135

2. Long KL, Sippel RS. Current and Future Treatments for Parathyroid Carcinoma. Int J Endo Oncol (2018) 5(1):IJE06. doi: 10.2217/ije-2017-0011

3. Fingeret AL. Contemporary Evaluation and Management of Parathyroid Carcinoma. JCO Oncol Pract (2021) 17(1):17-21. doi: 10.1200/JOP.19.00540

4. Wang P, Xue S, Wang S, Lv Z, Meng X, Wang G, et al. Clinical Characteristics and Treatment Outcomes of Parathyroid Carcinoma: A Retrospective Review of 234 Cases. Oncol Lett (2017) 14(6):7276-82. doi: 10.3892/ol.2017.7076

5. Cardoso L, Stevenson M, Thakker RV. Molecular Genetics of Syndromic and Non-Syndromic Forms of Parathyroid Carcinoma. Hum Mut (2017) 38:1621-48. doi: 10.1002/humu.23337

6. Hendy GN, Cole DEC. Genetic Defects Associated With Familial and Sporadic Hyperparathyroidism. Front Horm Res (2013) 41:149-65. doi: 10.1159/000345675

7. Alvelos MI, Mendes M, Soares P. Molecular Alterations in Sporadic Primary Hyperparathyroidism. Genet Res Int (2011) 2011:275802. doi: 10.4061/2011/ 275802

8. Pandya C, Uzilov AV, Bellizzi J, Lau CY, Moe AS, Strahl M, et al. Genomic Profiling Reveals Mutational Landscape in Parathyroid Carcinomas. JCI Insight (2017) 2(6):e92061. doi: 10.1172/jci.insight.92061

9. Svedlund J, Barazeghi E, Stålberg P, Hellman P, Åkerström G, Björklund P, et al. The Histone Methyltransferase EZH2, an Oncogene Common to Benign and Malignant Parathyroid Tumors. Endocr Relat Cancer (2014) 21(2):231-9. doi: 10.1530/ERC-13-0497

10. Yu W, McPherson JR, Stevenson M, van Eijk R, Heng HL, Newey P, et al. Whole-Exome Sequencing Studies of Parathyroid Carcinomas Reveal Novel PRUNE2 Mutations, Distinctive Mutational Spectra Related to APOBECCatalyzed DNA Mutagenesis and Mutational Enrichment in Kinases Associated With Cell Migration and Invasion. J Clin Endocrinol Metab (2015) 100(2):E360-4. doi: 10.1210/jc.2014-3238

11. Kasaian K, Wiseman SM, Thiessen N, Mungall KL, Corbett RD, Qian JQ, et al. Complete Genomic Landscape of a Recurring Sporadic Parathyroid Carcinoma. J Pathol (2013) 230(3):249-60. doi: 10.1002/path.4203

12. Gill AJ, Lim G, Cheung VKY, Andrici J, Perry-Keene JL, Paik J, et al. Parafibromin-Deficient (HPT-JT Type, CDC73 Mutated) Parathyroid Tumors Demonstrate Distinctive Morphologic Features. Am J Surg Pathol (2019) 43(1):35-46. doi: 10.1097/PAS.0000000000001017

13. Pontikides N, Karras S, Kaprara A, Anagnostis P, Mintziori G, Goulis DG, et al. Genetic Basis of Familial Isolated Hyperparathyroidism: A Case Series and a Narrative Review of the Literature. J Bone Miner Metab (2014) 32 (4):351-66. doi: 10.1007/s00774-013-0551-9

14. Hewitt KM, Sharma PK, Samowitz W, Hobbs M. Aberrant Methylation of the HRPT2 Gene in Parathyroid Carcinoma. Ann Otol Rhinol Laryngol (2007) 116(12):928-33. doi: 10.1177/000348940711601210

15. Yart A, Gstaiger M, Wirbelauer C, Pecnik M, Anastasiou D, Hess D, et al. The HRPT2 Tumor Suppressor Gene Product Parafibromin Associates With Human PAF1 and RNA Polymerase II. Mol Cell Biol (2005) 25(12):505260. doi: 10.1128/MCB.25.12.5052-5060.2005

16. Rozenblatt-Rosen O, Hughes CM, Nannepaga SJ, Shanmugam KS, Copeland TD, Guszczynski T, et al. The Parafibromin Tumor Suppressor Protein Is Part of a Human Paf1 Complex. Mol Cell Biol (2005) 25(2):612-20. doi: 10.1128/ MCB.25.2.612-620.2005

17. Haven CJ, Howell VM, Eilers PH, Dunne R, Takahashi M, van Puijenbroek M, et al. Gene Expression of Parathyroid Tumors: Molecular Subclassification and Identification of the Potential Malignant Phenotype. Cancer Res (2004) 64:e7405-11. doi: 10.1158/0008-5472.CAN-04-2063

18. Kim JM, Kim K, Punj V, Liang G, Ulmer TS, Lu W, et al. Linker Histone H1.2 Establishes Chromatin Compact and Gene Silencing Through Recognition of H3k27me3. Sci Rep (2015) 5:16714. doi: 10.1038/srep16714

19. Yang YJ, Han JW, Youn HD, Cho EJ. The Tumor Suppressor, Parafibromin, Mediates Histone H3 K9 Methylation for Cyclin D1 Repression. Nucleic Acids Res (2010) 38(2):382-90. doi: 10.1093/nar/gkp991

20. Ng HH, Dole S, Struhl K. The Rtf1 Component of the Paf1 Transcriptional Elongation Complex Is Required for Ubiquitination of Histone H2B. J Biol Chem (2003) 278(36):33625-8. doi: 10.1074/jbc.C300270200
21. Mosimann C, Hausmann G, Basler K. Parafibromin/Hyrax Activates Wnt/Wg Target Gene Transcription by Direct Association With Beta-Catenin/ Armadillo. Cell (2006) 125(2):327-41. doi: 10.1016/j.cell.2006.01.053

22. Lin L, Czapiga M, Nini L, Zhang JH, Simonds WF. Nuclear Localization of the Parafibromin Tumor Suppressor Protein Implicated in the Hyperparathyroidism-Jaw Tumor Syndrome Enhances Its Proapoptotic Function. Mol Cancer Res (2007) 5(2):183-93. doi: 10.1158/15417786.MCR-06-0129

23. Panicker LM, Zhang JH, Dagur PK, Gastinger MJ, Simonds WF. Defective Nucleolar Localization and Dominant Interfering Properties of a Parafibromin L95P Missense Mutant Causing the Hyperparathyroidism-Jaw Tumor Syndrome. Endocr Relat Cancer (2010) 17(2):513-24. doi: 10.1677/ ERC-09-0272

24. Tan MH, Morrison C, Wang P, Yang X, Haven CJ, Zhang C, et al. Loss of Parafibromin Immunoreactivity Is a Distinguishing Feature of Parathyroid Carcinoma. Clin Cancer Res (2004) 10(19):6629-37. doi: 10.1158/10780432.CCR-04-0493

25. Imanishi Y, Hosokawa Y, Yoshimoto K, Schipani E, Mallya S, Papanikolaou A, et al. Primary Hyperparathyroidism Caused by Parathyroid-Targeted Overexpression of Cyclin D1 in Transgenic Mice. J Clin Invest (2001) 107 (9):1093-102. doi: 10.1172/JCI10523

26. Mallya SM, Gallagher JJ, Wild YK, Kifor O, Costa-Guda J, Saucier K, et al. Abnormal Parathyroid Cell Proliferation Precedes Biochemical Abnormalities in a Mouse Model of Primary Hyperparathyroidism. Mol Endocrinol (2005) 19(10):2603-9. doi: 10.1210/me.2005-0116

27. Arnold A, Kim HG, Gaz RD, Eddy RL, Fukushima Y, Byers MG, et al. Molecular Cloning and Chromosomal Mapping of DNA Rearranged With the Parathyroid Hormone Gene in a Parathyroid Adenoma. J Clin Invest (1989) 83(6):2034-40. doi: 10.1172/JCI114114

28. Tashiro $\mathrm{E}$, Maruki $\mathrm{H}$, Minato $\mathrm{Y}$, Doki $\mathrm{Y}$, Weinstein IB, Imoto $\mathrm{M}$. Overexpression of Cyclin D1 Contributes to Malignancy by Up-Regulation of Fibroblast Growth Factor Receptor 1 via the pRB/E2F Pathway. Cancer Res (2003) 63(2):424-31.

29. Sanpaolo E, Miroballo M, Corbetta S, Verdelli C, Baorda F, Balsamo T, et al. EZH2 and ZFX Oncogenes in Malignant Behaviour of Parathyroid Neoplasms. Endocrine (2016) 54(1):55-9. doi: 10.1007/s12020-016-0892-y

30. Cromer MK, Starker LF, Choi M, Udelsman R, Nelson-Williams C, Lifton RP, et al. Identification of Somatic Mutations in Parathyroid Tumors Using Whole-Exome Sequencing. J Clin Endocrinol Metab (2012) 97(9):E1774-81. doi: $10.1210 / j c .2012-1743$

31. Wei Z, Sun B, Wang ZP, He JW, Fu WZ, Fan, et al. Whole-Exome Sequencing Identifies Novel Recurrent Somatic Mutations in Sporadic Parathyroid Adenomas. Endocrinology (2018) 159(8):3061-8. doi: 10.1210/en.2018-00246

32. Svedlund J, Koskinen Edblom S, Marquez VE, Åkerström G, Björklund P, Westin G. Hypermethylated in Cancer 1 (HIC1), a Tumor Suppressor Gene Epigenetically Deregulated in Hyperparathyroid Tumors by Histone H3 Lysine Modification. J Clin Endocrinol Metab (2012) 97(7):E1307-15. doi: 10.1210/jc.2011-3136

33. Rascio F, Spadaccino F, Rocchetti MT, Castellano G, Stallone G, Netti GS, et al. The Pathogenic Role of PI3K/AKT Pathway in Cancer Onset and Drug Resistance: An Updated Review. Cancers (Basel) (2021) 13(16):3949. doi: 10.3390/cancers13163949

34. Tavanti GS, Verdelli C, Morotti A, Maroni P, Guarnieri V, Scillitani A, et al. Yes-Associated Protein 1 Is a Novel Calcium Sensing Receptor Target in Human Parathyroid Tumors. Int J Mol Sci (2021) 22(4):2016. doi: 10.3390/ ijms22042016

35. Storvall S, Leijon H, Ryhänen EM, Vesterinen T, Heiskanen I, Schalin-Jäntti C, et al. Filamin A and Parafibromin Expression in Parathyroid Carcinoma. Eur J Endocrinol (2021) 185(6):803-12. doi: 10.1530/EJE-21-0668

36. Mingione A, Verdelli C, Ferrero S, Vaira V, Guarnieri V, Scillitani A, et al. Filamin A Is Reduced and Contributes to the CASR Sensitivity in Human Parathyroid Tumors. J Mol Endocrinol (2017) 58(2):91-103. doi: 10.1530/JME-16-0184

37. Verdelli C, Avagliano L, Guarnieri V, Cetani F, Ferrero S, Vicentini L, et al. Expression, Function, and Regulation of the Embryonic Transcription Factor TBX1 in Parathyroid Tumors. Lab Invest (2017) 97(12):1488-99. doi: 10.1038/labinvest.2017.88

38. Juhlin CC, Kiss NB, Villablanca A, Haglund F, Nordenstrom J, Hoog A, et al. Frequent Promoter Hypermethylation of the APC and RASSF1A Tumour 
Suppressors in Parathyroid Tumours. PloS One (2010) 5:e9472. doi: 10.1371/ journal.pone.0009472

39. Sulaiman L, Juhlin CC, Nilsson IL, Fotouhi O, Larsson C, Hashemi J. Global and Gene-Specific Promoter Methylation Analysis in Primary Hyperparathyroidism. Epigenetics (2013) 8:646e655. doi: 10.4161/epi.24823

40. Starker LF, Svedlund J, Udelsman R, Dralle H, Akerström G, Westin G, et al. The DNA Methylome of Benign and Malignant Parathyroid Tumors. Genes Chromosomes Cancer (2011) 50:735-45. doi: 10.1002/gcc.20895

41. Svedlund J, Aurén M, Sundström M, Dralle H, Akerström G, Björklund P, et al. Aberrant WNT/beta-Catenin Signaling in Parathyroid Carcinoma. Mol Cancer (2010) 9:294. doi: 10.1186/1476-4598-9-294

42. Carling T, Du Y, Fang W, Correa P, Huang S. Intragenic Allelic Loss and Promoter Hypermethylation of the RIZ1 Tumor Suppressor Gene in Parathyroid Tumors and Pheochromocytomas. Surgery (2003) 134(6):932939; discussion 939-940. doi: 10.1016/s0039-6060(03)00422-7

43. Singh P, Bhadada SK, Arya AK, Saikia UN, Sachdeva N, Dahiya D, et al. Aberrant Epigenetic Alteration of PAX1 Expression Contributes to Parathyroid Tumorigenesis. J Clin Endocrinol Metab (2021) 107(2):e783-92. doi: 10.1210/clinem/dgab626

44. Rahbari R, Holloway AK, He M, Khanafshar E, Clark OH, Kebebew E. Identification of Differentially Expressed microRNA in Parathyroid Tumors. Ann Surg Oncol (2011) 18:1158-65. doi: 10.1245/s10434-010-1359-7

45. Corbetta S, Vaira V, Guarnieri V, Scillitani A, Eller-Vainicher C, Ferrero S, et al. Differential Expression of microRNAs in Human Parathyroid Carcinomas Compared With Normal Parathyroid Tissue. Endocr Relat Cancer (2010) 17(1):135-46. doi: 10.1677/ERC-09-0134

46. Vaira V, Elli F, Forno I, Guarnieri V, Verdelli C, Ferrero S, et al. The microRNA Cluster C19MC Is Deregulated in Parathyroid Tumours. J Mol Endocrinol (2012) 49(2):115-24. doi: 10.1530/JME-11-0189

47. Zhang X, Hu Y, Wang M, Zhang R, Wang P, Cui M, et al. Profiling Analysis of Long Non-Coding RNA and mRNA in Parathyroid Carcinoma. Endocr Relat Cancer (2019) 26(2):163-76. doi: 10.1530/ERC-18-0480

48. Morotti A, Forno I, Verdelli C, Guarnieri V, Cetani F, Terrasi A, et al. The Oncosuppressors MEN1 and CDC73 Are Involved in lncRNA Deregulation in Human Parathyroid Tumors. J Bone Miner Res (2020) 35(12):2423-31. doi: $10.1002 / j \mathrm{jmr} .4154$

49. Lu Y, Xiao L, Liu Y, Wang H, Li H, Zhou Q, et al. MIR517C Inhibits Autophagy and the Epithelial-to-Mesenchymal (-Like) Transition Phenotype in Human Glioblastoma Through KPNA2-Dependent Disruption of TP53 Nuclear Translocation. Autophagy (2015) 11(12):2213-32. doi: 10.1080/ 15548627.2015.1108507

50. Liu RF, Xu X, Huang J, Fei QL, Chen F, Li YD, et al. Down-Regulation of miR-517a and miR-517c Promotes Proliferation of Hepatocellular Carcinoma Cells via Targeting Pyk2. Cancer Lett (2013) 329(2):164-73. doi: 10.1016/j.canlet.2012.10.027

51. Robson JE, Eaton SA, Underhill P, Williams D, Peters J. MicroRNAs 296 and 298 Are Imprinted and Part of the GNAS/Gnas Cluster and miR-296 Targets IKBKE and Tmed9. RNA (2012) 18(1):135-44. doi: 10.1261/rna.029561.111

52. Liu S, Wang Z, Liu Z, Shi S, Zhang Z, Zhang J, et al. miR-221/222 Activate the Wnt/beta-Catenin Signaling to Promote Triple-Negative Breast Cancer. J Mol Cell Biol (2018) 10(4):302-15. doi: 10.1093/jmcb/mjy041

53. Wang KC, Chang HY. Molecular Mechanisms of Long Noncoding RNAs. Mol Cell (2011) 43:904-14. doi: 10.1016/j.molcel2011.08.018

54. Knoll M, Lodish HF, Sun L. Long Non-Coding RNAs as Regulators of the Endocrine System. Nat Rev Endocrinol (2015) 11(3):151-60. doi: 10.1038/ nrendo.2014.229

55. Bartonicek N, Maag JL, Dinger ME. Long Noncoding RNAs in Cancer: Mechanisms of Action and Technological Advancements. Mol Cancer (2016) 15(1):43. doi: 10.1186/s12943-016-0530-6

56. Schmitt AM, Chang HY. Long Noncoding RNAs in Cancer Pathways. Cancer Cell (2016) 29(4):452-63. doi: 10.1016/j.ccell.2016.03.010

57. Murugan AK, Munirajan AK, Alzahrani AS. Long Noncoding RNAs: Emerging Players in Thyroid Cancer Pathogenesis. Endocr Relat Cancer (2018) 25(2):R59-82. doi: 10.1530/ERC-17-0188

58. Samson J, Cronin S, Dean K. BC200 (BCYRN1) - The Shortest, Long, NonCoding RNA Associated With Cancer. Noncoding RNA Res (2018) 3(3):13143. doi: $10.1016 /$ j.ncrna.2018.05.003
59. Wan L, Sun M, Liu GJ, Wei CC, Zhang EB, Kong R, et al. Long Noncoding RNA PVT1 Promotes Non-Small Cell Lung Cancer Cell Proliferation Through Epigenetically Regulating LATS2 Expression. Mol Cancer Ther (2016) 15(5):1082-94. doi: 10.1158/1535-7163.MCT-15-0707

60. Hu Y, Zhang X, Cui M, Wang M, Su Z, Liao Q, et al. Circular RNA Profile of Parathyroid Neoplasms: Analysis of Co-Expression Networks of Circular RNAs and mRNAs. RNA Biol (2019) 16(9):1228-36. doi: 10.1080/ 15476286.2019.1622962

61. Condello V, Cetani F, Denaro M, Torregrossa L, Pardi E, Piaggi P, et al. Gene Expression Profile in Metastatic and Non-Metastatic Parathyroid Carcinoma. Endocr Relat Cancer (2021) 28(2):111-34. doi: 10.1530/ERC-20-0450

62. Ciregia F, Cetani F, Pardi E, Soggiu A, Piras C, Zallocco L, et al. Parathyroid Carcinoma and Adenoma Co-Existing in One Patient: Case Report and Comparative Proteomic Analysis. Cancer Genomics Proteomics (2021) 18 (6):781-96. doi: 10.21873/cgp.20297

63. Song IK, Kim HJ, Magesh V, Lee KJ. Ubiquitin C-Terminal Hydrolase-L1 Plays a Key Role in Angiogenesis by Regulating Hydrogen Peroxide Generated by NADPH Oxidase 4. Biochem Biophys Res Commun (2018) 495(1):1567-72. doi: 10.1016/j.bbrc.2017.11.051

64. Kim HJ, Magesh V, Lee JJ, Kim S, Knaus UG, Lee KJ. Ubiquitin C-Terminal Hydrolase-L1 Increases Cancer Cell Invasion by Modulating Hydrogen Peroxide Generated via NADPH Oxidase 4. Oncotarget (2015) 6(18):16287162303. doi: 10.18632/oncotarget. 3843

65. Luo Y, He J, Yang C, Orange M, Ren X, Blair N, et al. UCH-L1 Promotes Invasion of Breast Cancer Cells Through Activating Akt Signaling Pathway. J Cell Biochem (2018) 119(1):691-700. doi: 10.1002/jcb.26232

66. Jin Y, Zhang W, Xu J, Wang H, Zhang Z, Chu C, et al. UCH-L1 Involved in Regulating the Degradation of EGFR and Promoting Malignant Properties in Drug-Resistant Breast Cancer. Int J Clin Exp Pathol (2015) 8(10):12500-8.

67. Wang W, Zou L, Zhou D, Zhou Z, Tang F, Xu Z, et al. Overexpression of Ubiquitin Carboxyl Terminal Hydrolase-L1 Enhances Multidrug Resistance and Invasion/Metastasis in Breast Cancer by Activating the MAPK/Erk Signaling Pathway. Mol Carcinog (2016) 55(9):1329-42. doi: 10.1002/ mc. 22376

68. Wang YP, Zhou W, Wang J, Huang X, Zuo Y, Wang TS, et al. Arginine Methylation of MDH1 by CARM1 Inhibits Glutamine Metabolism and Suppresses Pancreatic Cancer. Mol Cell (2016) 64(4):673-87. doi: 10.1016/ j.molcel.2016.09.028

69. Peng JM, Lin SH, Yu MC, Hsieh SY. CLIC1 Recruits PIP5K1A/C to Induce Cell-Matrix Adhesions for Tumor Metastasis. J Clin Invest (2021) 131(1): e133525. doi: 10.1172/JCI133525

70. Qiu Y, Mao YT, Zhu JH, Zhao K, Wang JF, Huang JM, et al. CLIC1 Knockout Inhibits Invasion and Migration of Gastric Cancer by Upregulating AMOTP130 Expression. Clin Transl Oncol (2021) 223(3):514-25. doi: 10.1007/ s12094-020-02445-0

71. Kim YS, Gupta Vallur P, Phaëton R, Mythreye K, Hempel N. Insights Into the Dichotomous Regulation of SOD2 in Cancer. Antioxidants (Basel) (2017) 6 (4):86. doi: 10.3390/antiox6040086

Conflict of Interest: The authors declare that the research was conducted in the absence of any commercial or financial relationships that could be construed as a potential conflict of interest.

Publisher's Note: All claims expressed in this article are solely those of the authors and do not necessarily represent those of their affiliated organizations, or those of the publisher, the editors and the reviewers. Any product that may be evaluated in this article, or claim that may be made by its manufacturer, is not guaranteed or endorsed by the publisher.

Copyright (c) 2022 Marini, Giusti, Palmini, Perigli, Santoro and Brandi. This is an open-access article distributed under the terms of the Creative Commons Attribution License (CC BY). The use, distribution or reproduction in other forums is permitted, provided the original author(s) and the copyright owner(s) are credited and that the original publication in this journal is cited, in accordance with accepted academic practice. No use, distribution or reproduction is permitted which does not comply with these terms. 